\title{
Satellite Power System (SPS) Student Participation
}

October 1978

\section{U.S. Department of Energy}

Office of Energy Research

Satellite Power System Project Office

Washington, D.C. 20545

Under Contract No. EG-77-C-01-4024

\section{DOE/NASA}

SATELLITE POWER SYSTEM

Concept Development and

Evaluation Program 
Avallable from:

National Technical Information Service (NTIS)

U.S. Department of Commerce

5285 Port Royal Road

Springfield, Virginia 22161

Price: Printed copy: $\$ 6.00$

Microf Iche: $\$ 3.00$ 


\section{Satellite Power System (SPS) Student Participation}

October 1978

Prepared by:

Alan Ladwig, Project Director

Leonard David, Principal Investigator

Forum for the Advancement of

Students in Science and Technology

Washington, D.C. 20036

for the

PRC Energy Analysis Company

McLean, Virginia 22102

Prepared for:

U.S. Department of Energy

Office of Energy Research

Satellite Power System Project Office

Washington, D.C. 20545

Under Contract No. EG-77-C-01-4024

\section{DOE/NASA}

SATELLITE POWER SYSTEM

Concept Development

and

Evaluation Program 


\section{NOTICE}

This report was prepared as an account of work sponsored by the United States Government. Neither the United States nor the United States Department of Energy, nor any of their employees, makes any warranty, express or implied, or assumes any legal liability or responsibility for the accuracy, completeness, or usefulness of any information, apparatus, product, or process disclosed, or represents that its use would not infringe privately owned rights. Reference herein to any specific commercial product, process, or service by trade name, mark, manufacturer, or otherwise, does not necessarily constitute or imply its endorsement, recommendation, or favoring by the United States Government or any agency thereof. The views and opinions of authors expressed herein do not necessarily state or reflect those of the United States Government or any apency thereof. 
The author acknowledges the following people for their review of the first draft of this White Paper:

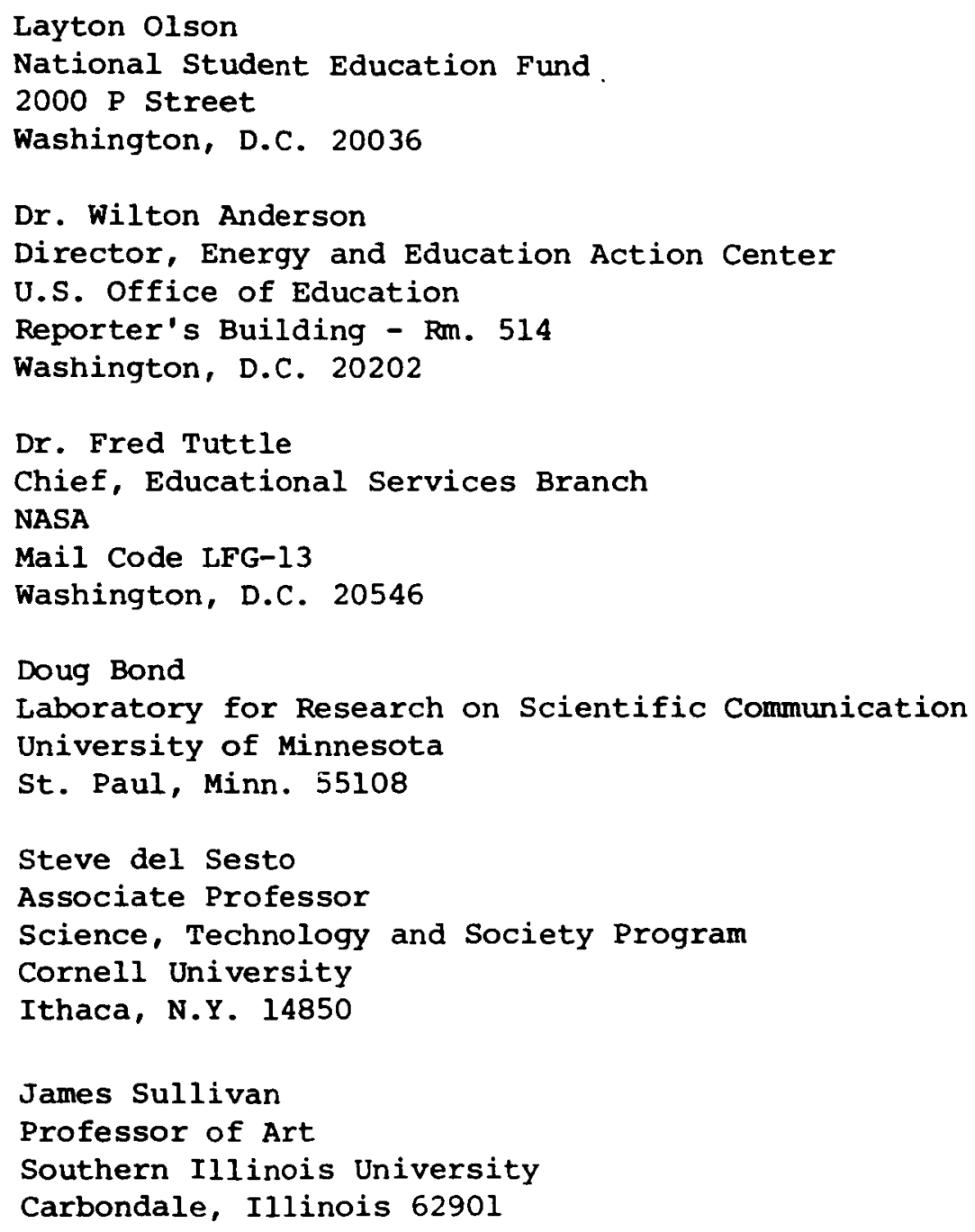




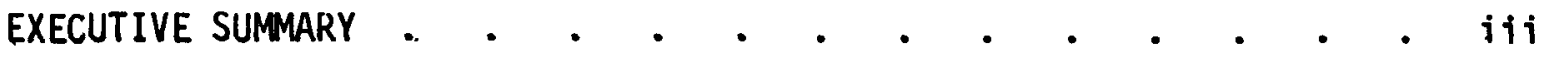

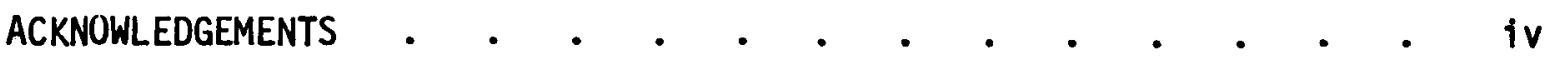

I. INTRUDUCTION

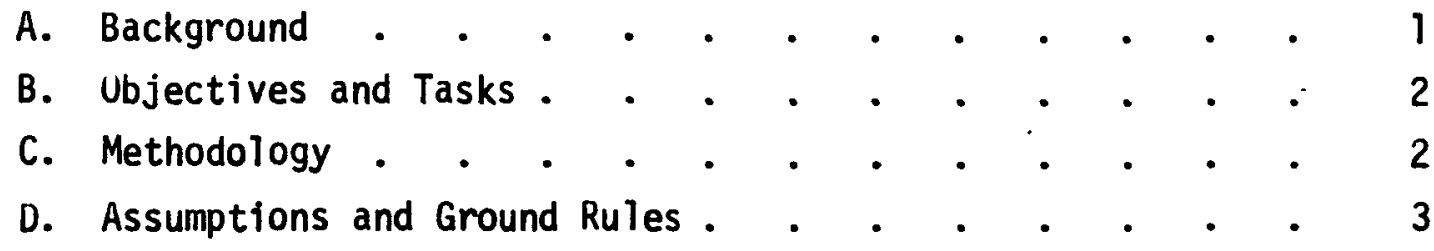

II. SURVEY OF RELEVANT LITERATURE AND RELATED WORK

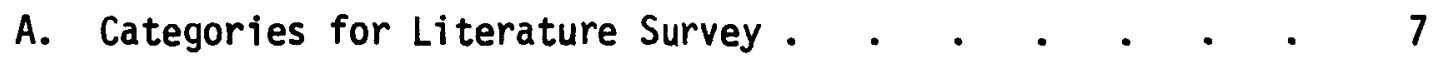

B. Trends Observed in the Literature Survey . . . . . 7

III. ANALYSIS AND EVALUATION

A. Current State of Affairs . . . . . . . . . 13

B. Criteria to Select Student Participation Methods . . . . . . . . . . . . . 17

C. Methods for Student Participation in the
SPS Discussion

1. Classroom Activities . . . . . . . . . . 22

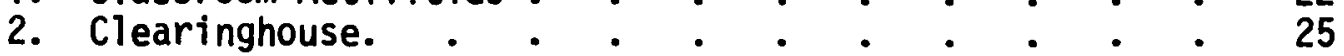

3. Computer-Based Methods : . . . . . . . . . 26

4. Field Trips . . . . . . . . . . . 29

5. Lecture Series and Presentations . . . . . . 31

6. Meetings and Conferences . . . . . . . . 33

7. Mobile Presentations . . . . . . . . . 36

8. Problem/Possibility Institutes and
Networks. . . . . . . . 38

9. Public Hearings . . . . . . . . . . 41

10. Radio Programs and Networks . . . . . . . 42

11. Satellite Communications . . . . . . . . 44

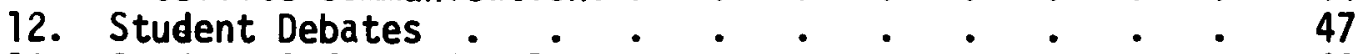

13. Student Information Programs . . . . . . . 49

14. Student Internships . . . . • . . • . 51

15. Surveys and questionnaires . . . . . . . 54

16. Telelectures . • . . . . . • . . . . 56

17. Videotape. • • • • • • • • • • • 57

IV. KEY ISSUES AND GENERAL OBSERVATIONS

A. Extent and Amount of Involvement . • . • • • . 63

B. Capacity to Manage Involvenent . . . . . . . 64

C. Utilization of Student Participation . . . . . . 64

D. Available Funding for Student Participation . . . . 65

E. Interface With Education Divisions . . . . . . 65

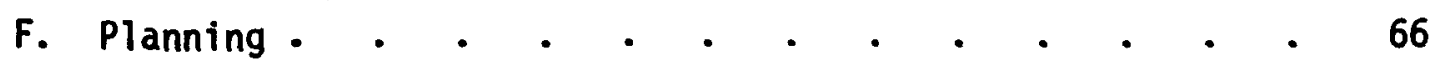

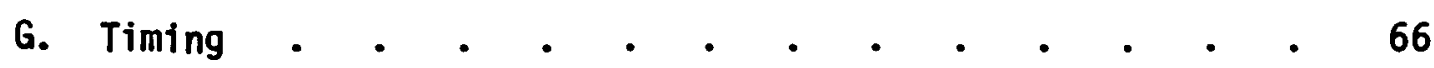


V. RECOMMENDATIONS FOR FURTHER STUDY. • . . . . . . . 67

A. Recommendations for Student Participation in SPS Discussion.

B. Recommendations for Student Participation to Other Issues

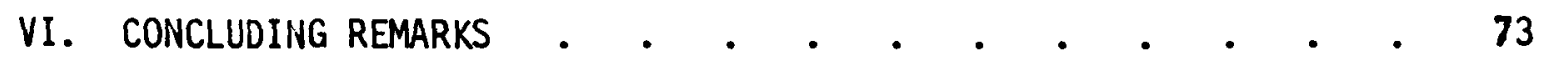

VII. REFERENCES • • • • • • • • • • • • • • 75

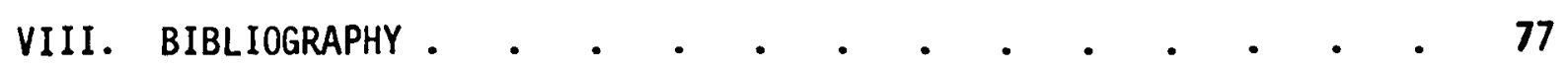

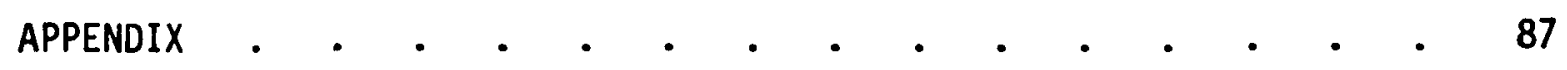


The purpose of this paper is to present a preliminary assessment of methods which are appropriate to initiate student participation in the discussion of a Satellite Power System (SPS). Often considered as an element of a broader citizen participation effort, this assessment of student participation focuses on those methods which can be incorporated into the campus environment and the on-going learning experience. For the purposes of this paper, we have considered "students" to be those who are pursuing an education at two and four-year post-secondary institutions.

The review of the literature and related materials was centered on information and ideas from those engaged in day-to-day delivery of student services and programs. This search revealed that, while many practitioners are convinced that the need to promote student participation programs in societal issues is great, in-depth research on how to realize this objective is lacking. The current re-evaluation of the concept of general education, launched by the academic community, presents an opportunity to up-grade consideration of how to make student participation activities more effective.

Before examining an analysis of specific methods, the paper suggests eight criteria to help evaluate functions of the methods. These criteria recognize the diversity of the student population, their transient nature, and the necessity to provide opportunities geared to meet different interests and situations.

The discussion of individual methods for student participation includes a description of the technique, followed by comments on its enhancing and limiting factors, references to situations where the method has been demonstrated, and a brief consideration of cost factors. The paper describes seventeen methods.

Before decisions can be made on the methods which deserve closer examination, important questions must be answered concerning the nature of student participation desired by DOE. The extent of involvement by students, DOE's capacity to manage the participation, how $D O E$ intends to utilize student input, how much funding will be available, the level of interface with other federal education offices, and elements of planning and timing, must all be considered when determining appropriate methods to initiate a student participation program.

The paper concludes with two categories of recommendations. The first category outlines fourteen recommendations addressing specific activities related to student participation in the discussion of SPS. The second category outlines three recommendations pertaining to student participation activities in general. 


\section{ACKNOWLEDGEMENTS}

The authors wish to gratefully acknowledge the following individuals who served as peer reviewers for this paper: Dr. Wilton Anderson, Energy and Education Action Center, Office of Education; Mr, Doug Bond, Laboratory for Research in Scientific Communicatton. University of Michigan; Mr. Steven Del Sesto, Program on Science, Technology and Society, Cornel1 University; Mr. Layton 01son, National Student Education Fund; Mr. James Sullivan, Department of Art, Southern Illinois University; and, Dr. Fred Tuttle, Educational Programs, National Aeronautics and Space Ad-. ministration. The organizations of the reviewers are listed for identification only, and do not represent an endorsement of the findings of this paper. 


\section{INTRODUCTION}

\section{A. BACKGROUND}

The Department of Energy (DOE) and the National Aeronautics and Space Administration (NASA) are currently engaged in a joint concept development and evaluation program to reach, by the end of 1980, an initial understanding of the technical feasibility, economic practicality and social and environmental acceptability of the Satellite Power System (SPS)* concept. 1

The concept of SPS is designed to capture solar energy with a satellite(s) in geosynchronous orbit and convert it to electric energy by photovoltaics (solar cells). This energy, in turn, would be converted to radiofrequency energy and beamed to Earth in a focused beam aimed at a ground receiving antenna (rectenna), where it would be reconverted to electricity for distribution in a utility grid. Each rectenna will provide 5000 megawatts (5 gigawatts) of electrical power to the grid.

The evaluation program by DOE/NASA includes four functional study areas: systems definition; evaluation of environmental, health, and safety factors; related socioeconomic issues; and comparative assessment of al ternative systems.

The PRC Energy Analysis Company, a division of the Planning Research Company, has been contracted to coordinate the study of the socioeconomic components of the SPS evaluation. These components include: an assessment of necessary resources; land use studies; federal involvement; regulatory impacts; international agreements; organizational structures; military implications; utility integration; industrial and population relocation; centralization/ decentralization; public acceptance; and as a corollary to public acceptance, an assessment of student participation methods.

* In much of the literature on this topic, SPS is also an abbreviation for Solar Power Satellite. 
The Forum for the Advancement of Students in Science and Technology, Inc. (FASST) has been designated by PRC to investigate that portion of the socioeconomic study addressing methods to significantly involve students in an on-going discussion of issues related to SPS.

\section{B. OBJECTIVES AND TASKS}

The objective assigned to this paper is to assess various methods and procedures that might prove suitable to involve students in the discussion of SPS issues.

To accomplish the above objective, the Forum was assigned the following tasks.

Task 1: Survey and identify potential methods that can be utilized to communicate information to the college community regarding the concept and implications of a satellite power system.

Task 2: Investigate methods of conflict management that can be applied in the dissemination of information on SPS. 2

As the study progressed, it became apparent to the Forum and the study sponsors that not only should the paper describe methods to communicate information to the college student community, but an attempt to gain student feedback regarding the information, should also be made. Therefore Task 1 was expanded to include the identification of methods for students to provide feedback of their ideas, opinions, and concerns regarding SPS issues.

\section{c. METHODOLOGY}

To achieve the set objectives and carry out the indicated tasks, this paper (in accordance with the required format) will include:

- A survey of relevant literature and related work;

- An analysis and evaluation of relevant findings;

- A determination of key issues and general observations;

- Recommendations for further study; and a 
- Bibliography and an Appendix.

The study was conducted from July 1 through October 1, 1978. The study agreement stipulated that the Forum would submit to PRC: monthly progress reports (due by the 10th of the following month); a draft "White Paper" for peer review (due on September 1); a final White Paper (due October 17); and an oral presentation on the findings to be made at a Societal Assessment Review of the SPS concept (on October 27).

\section{ASSUMPTIONS AND GROUND RULES}

As one reviews the findings and recommendations presented in this paper, the authors would like to state certain biases, assumptions, and ground rules that guided the study:

1. Student participation in the SPS discussion is appropriate because of the generally accepted proposition that in a free society, all those affected by a societal policy have a right to a voice in its formation;

2. Our discussion of student participation will concentrate on activities that are unique to the campus environment and resources rather than the broader discussion of citizen participation activities;

3. The motivation of the SPS Project Office to include student participation is to develop effective educational programs and is not an attempt to manipulate student beliefs, attitudes, or actions toward a predetermined goal or set of goals;

4. For the purposes of this study, we have adopted the following definition of education -- the presentation of various dimensions of an issue to include the grounds for doubting as well 
as the grounds for believing statements, advantages and disadvantages. This process aims to induce students to collect and evaluate evidence for themselves and to assist students in learning the techniques for doing so. 3

5. The SPS Project Office instructed those involved in the various components of the study not to take a position concerning SPS as an energy resource. We neither oppose their construction nor support the construction of SPS as a matter of principle. As an organization, the Forum follows a similar policy for all science issues we discuss; and,

6. For the purposes of this study, we have considered "students" as those who are pursuing an education at 2 and 4 year postsecondary institutions.

The information and findings presented in this paper will be used as a base for on-going documentation of student participation methods. While the paper addresses participation methods around the topic of a Satellite Power System, it is our intention to continue to refine our ideas and recommendations to be applied to the discussion of other science and technology issues. We, therefore, invite comments and suggestions from the reader as contributions to the improvement of student participation efforts.

For additional information regarding the findings of this paper, please contact:

Alan Ladwig/Project Director Leonard David/Principal Investigator Forum for the Advancement of Students in Science and Technology, Inc. 2030 M Street, N.W., Suite 402 Washington, D.C. 20036 
For additional information on the overall socioeconomic portion of the SPS study, please contact:

Charles Bloomquist

PRC Systems Sciences Company

10960 Wilshire Boulevard, Suite 2340

Los Angeles, California 90024

$213 / 477-8278$

For additional information on the overall SPS study being conducted by the Department of Energy, please contact:

Fred Koomanoff

Director, SPS Project Office

Office of Energy Research

Department of Energy

Washington, D.C. 20416

$202 / 376-9275$ 


\section{SURVEY OF RELEVANT LITERATURE AND RELATED WORK}

\section{A. CATEGORIES FOR LITERATURE SURVEY}

In order to provide a base of information relevant to the assigned objectives, the following topic categories were established for the literature survey:

- Citizen Participation Projects

- Communication Mechanism Projects

- Conflict Management

- Dissemination of Science Information

- Energy Education/Awareness Programs

- Ethics and Values in Science

- Public Understanding of Science

- Networks to Reach Student Community

- Student Programs/Student Involvement

These general categories served as guidelines for a more specific literature search and provided relevant materials to each task.

Materials for these categories were primarily obtained from interviewing individuals associated with organizations or academic departments who had a general interest in the area of citizen participation. The information from these sources arrived in the form of conference proceedings; technical reports; surveys; interview notes; professional publications; books; magazine articles; films; video tapes; film strips; bibliographies; and computer printouts. The Forum's files for this study and the 140+ documents that were collected under the above categories are available for use to any individual or organization interested in either student involvement in general or SPS in particular.

B. TRENDS OBSERVED IN THE LITERATURE SURVEY

While the specific information gained from the literature survey is dealt with in the "Analysis and Evaluation" section of this paper, there are 
areas of commonality in the nature of the literature that we believe should be noted:

1. Accompanying the growing awareness of the impact which science and technology has on our lives has been the growing demand for citizen participation in the decision-making process related to these issues.

Technological issues such as nuclear power, the supersonic transport, recombinant DNA molecule research, and solar energy have spawned numerous interest groups and ad hoc coalitions who feel they can make a valuable contribution to the discussion of these issues, which many feel are too important to be left to the experts.

There are, however, others who feel that this increased demand for public participation only complicates the process of policy development. There is a growing skepticism that government will be able to design a participation system that will not impair the whole decision-making process.

2. The growing amount of literature appearing on the topic of citizen participation on energy issues tends to focus on the need for this input rather than on how it can be done most effectively.

As one professor cormented, "Citizen participation on energy issues has become the new 'Motherhood' issue." Much of the literature states why citizens have a right to be involved in these discussions and the important role they have played in matters such as nuclear power and solar energy. What appears to be lacking is an in-depth analys is of how to make this participation most effective, in view of issues which involve complex social, economic, and technological problems.

3. References to the vast experience of citizen participation in issues related to transportation planning, model cities programs, and water 
resources planning do not often appear in the literature related to citizen participation on energy issues.

Certain divisions of the Department of Transportation and the Department of Health, Education, and Welfare have been active in citizen participation programs for the past two decades. Those who are now active in the push for a greater citizen's role in the energy discussion could discover much from what has been learned at the above mentioned agencies.

This situation may be improved in the years ahead as a result of the "First National Conference on Citizen Participation", sponsored by the Lincoln Filene Center for Citizenship and Public Affairs at Tufts University. Held in Washington, D.C., the conference featured 70 speakers in panel and workshop sessions on a broad range of citizen participation opportunities and issues. The 600 participants, representing civic organizations, goverment agencies, universities, and consumer groups, shared volumes of information and printed material. The conference is scheduled to become an annual event and should make a significant contribution towards the exchange of information on participation methods and issues.

4. While there is much being written on citizen participation in general, literature on "student" participation is a lmost nonexistent.

The available literature certainly does not exclude students from the participation process, however we have been unable to discover a significant amount of material which concentrates on circumstances and opportunities unique to the student community.

There has also been little written in terms of an evaluation of student participation programs. While many of those who are student program practitioners are aware of the need for such evaluations to occur, this is an area that has not progressed very far in the student community. We believe this 
is due to the high degree of staff turnover at student organizations, as well as to the lack of available funding to conduct efficient program evaluations.

5. There appears to be a shortage of literature which discusses the relationship between educational programs generated off-campus and their contribution to a student's traditional learning experience.

Most of our findings and recommendations on how student involvement in the SPS discussion can supplement the traditional learning experience are based on the results of group meetings and individual interviews. We welcome the identification of sources where this area has been treated in a more scholarly manner.

6. Educational programs generated by off-campus organizations do not rank on the priority list of government agencies when it comes to program or funding support.

Because of the need to get the "most program for the tax dollar," government agencies such as the National Science Foundation, the Department of Energy, the National Aeronautics and Space Administration, and the Office of Education, have not given a significant amount of financial support to educational programs proposed by off-campus national student organizations. These agencies tend to focus on programs that will reach large and diverse audiences through the mass media or through curriculum improvement projects for teachers.

At this point, this observation is not offered as criticism. It is merely mentioned as a reason for the apparent lack of literature that these agencies were able to offer to this study.

7. Generalizations about what constitutes "the" student opinion should be evaluated carefully when discussing science issues or, for that matter, other societal issues. 
The student population is not a monolith which is for or against a particular issue, as many oversimplified statements about "the" college community, or "the" young would have us believe. The opinions and attitudes of college students vary according to the issues under discussion and will be influenced by other factors and values than just the presence of the individual on campus.

8. More than one-third of today's college students are 25 or older. According to U.S. Census Bureau data, in 1977 about $36 \%$ of the college student population were at least 25 years old. Five years ago this group made up $28 \%$ of the campus community. The upward trend of older students on campus will very likely bring about changes in the nature of campus life and activities in the years ahead. 


\section{ANALYSIS AND EVALUATION}

\section{A. THE CURRENT STATE OF AFFAIRS}

"Whether it's the best of times or the worst of times, it is the only time you've got... We, the older generation, have given you a perfect world, and we don't want you to do anything to louse it up."

Art Buchwald

August, 1978

In his speech before students at Emerson College, syndicated humorist Art Buchwald touched on a key reason why it is appropriate that students should participate in the discussion of a Iong range technological issue such as SPS. It is not without cause that some students have reservations about the world they will inherit, and therefore claim a right to offer their ideas and opinions on the shape of things to come.

Before presenting an analysis of what mechanisms might be useful to gain student participation in the SPS discussion, it seems appropriate to describe the current environment which has led to the increased emphasis on citizen participation in the decision-making process for energy issues.

When President Carter proclaimed that the need to create a comprehensive national energy policy was the moral equivalent to war, many felt that a positive step had been taken toward a battle plan to beat the energy crisis. Yet, over a year after the President declared this war and submitted his National Energy Plan to Congress, we have no comprehensive plan. Not only have we no plan, but those charged with the responsibility to approve a strategy do not seem to be able to agree on what the "enemy" is. While the leaders continue to fight each other, the situation grows worse and the public is more confused than ever as to what they should do to act in a responsible manner to support the "war" effort.

Energy "experts" are creating a sense of helplessness among the 
public by sending out a vast amount of conflicting information on the energy situation. Some experts tell us that we must concentrate on production and move forward with continued economic growth, while other experts tell us to concentrate on conservation and begin to adopt naw life styles based on a concept of limited growth.

Many elements in society have hopes that science will discover some new technological "fix" that will snatch us from the jaws of the crisis, which will allow everyone to return to the business of realizing the American Dream. Yet, some writers, such as Robert Theobald suggest that "it has been our willingness to approve technological fixes for complex problems that has led us into our present critical situation." 4

Thus, the on-going Congressional and Administration confusion on how to conduct the battle, the conflicting views of energy experts, and the stark realization that there evidently is no technological fix, have all caused the public to re-evaluate the traditional political structures and their ability to make good decisions for society. Recent citizen surveys, such as those by the League of Women Voters, have shown that "skepticism and cynicism pervade citizen reaction to goverment. Distrust of politicians and government in general and utilities and energy companies continues to increase. Credibility is a serious and critical factor in trying to reach equitable solutions to energy problems." 5

In addition to the realization that our political structures have serious problems in dealing with the energy issues, comes the growing public awareness of the impacts of technological developments on society. In a study of citizen involvement in the nuclear power controversy, Steven Ebbin and Raphael Kasper, of George Washington University's Program of Policy Studies in Science and Technology, observed: 
"Since as a nation, we have become increasingiy dependent upon technological development for our economic well being, it is inevitable that the impact of technology has become an increasingly evident force affecting the everyday life of our citizens ...As a result, public awareness has grown, and has been accompanied by increased citizen demands for a significant role in the decision-making processes which underlie policies and investments, particularly, but not only in the public sector. Decisions about the applications of technology often involve considerations of human and societal values in which citizens have begun to seek a greater voice." 6

This focus on "human and societal values" has injected new language and new considerations into the discussion of energy policy planning. In addition to certain political, economic and scientific factors, policy planners must now become familiar with the issues of centralization versus decentralization, risk versus benefits, and abundance versus "enoughness". This emphasis on values results from the awareness of the social and environmental costs that accompany energy systems.

As the above conditions have set the stage for general citizen participation in the energy discussion, another series of events has been taking place in the college student community.

Throughout the past two years, a lively debate has been occurring in the academic community concerning the nature of what constitutes an adequate general (liberal) education for students. Should the university regain some of the control it delegated to students and faculty during the campus revolutions of the early $70^{\prime} s$ ? Should there be renewed emphas is on some kind of "core" curriculum? Do we need to do more to humanize the scientists and "scientize" the humanist?

The recent decision by Harvard to establish a core curriculum is likely to launch similar re-evaluations at other colleges and universities. The outcome of these re-evaluations and the general education debate will have a major impact on the types of educational experiences students will 
have in the future.

Another relevant factor on the state of affairs for students is the contention by many writers that the majority of students are negative and pessimistic about current conditions and the future direction of society. Some feel that students just criticize conditions without offering alternatives or without understanding the complexities of certain issues.

In tracing the causes for these negative feelings among students, Ed Cornish, President of the World Future Society, observed:

"This pessimism stems in large measure from their growing uncertainty about their own roles in the future, but pessimism also comes from overemphasis on the problems of the world. Many teachers feel they have a duty to warn young people about world problems, but too much dwelling on problems can result in so much pessimism that the young people feel that the effort is useless. Gloom is not the best mood for effective action".7

A third factor to take into consideration in setting the stage for student participation is to look at the previously mentioned age level of today's college students. "More than a third of today's college students are 25 or older, according to data from the U.S. Census Bureau. In 1977, about $36 \%$ of students were at least 25 years 01 , compared with $28 \%$ in the older group five years ago". 8

This upward trend of older students pursuing educational degrees could have a substantial impact on the complexion of the campus in the years ahead. The increase in the number of older students has particular bearing on the consideration of student participation in the discussion of science issues.

A final consideration to set the stage for student participation concerns the large number of foreign students enrolled in U.S. colleges and universities. According to a survey conducted by the Institute of International Education, 203,068 foreign students were enrolled at 2,524 institutions in 1976-77. The presence of such a large number of students from other 
countries can become a definite asset when discussing an issue with as many international implications as SPS.

With an understanding of conditions that have led to increased demands for general citizen participation, as well as an understanding of certain campus characteristics, we can now begin to outline criteria that will be necessary to involve students in a discussion of the SPS.

B. CRITERIA TO SELECT STUDENT PARTICIPATION METHODS

Student participation offers the greatest benefit to all concerned when viewed as an educational opportunity to apply classroom theory, resources, and learning to the SPS discussion. This view also distinguishes student participation from more general citizen participation.

The diverse needs and interests of students will require that these educational opportunities be placed within a flexible structure. Students, themselves, should be involved in developing methods for their participation. They must inform DOE how extensive their participation will be. Do they just want to be kept informed of SPS progress or do they want to actively participate in technical research throughout the SPS study? Since the answers to these questions are likely to differ from one group of students to the next, the participation structure must include a variety of methods to meet different levels of interest.

To determine which participation methods will lead to the most meaningful educational experiences for students, the authors suggest that DOE consider the following criteria as they develop the participation structure.

1. INCLUDES DISCUSSION OF BROADER ENERGY DISCUSSION

Many of our current energy problems are a result of our inability to educate people to view energy from a holistic perspective. Effective participation methods must involve ways for students to improve their understanding 
of the concept and implications of SPS in the context of the broader energy situation and alternative energy sources.

2. HIGHLIGHTS INDIVIDUAL EXPERIENCE

When selecting methods to include in the overall participation structure, DOE should look for opportunities which highlight individual, active experiences for the student. According to Dartmouth sociology professor $\mathrm{H}$. Wentworth Eldredge, "modern students appear to learn faster and with more enthusiasm if they participate very actively in producing knowledge rather than reading about the process." 9 Such an approach will enhance the efforts of those students who are seeking in-depth participation opportunities and want to have a direct influence in the discussions that will affect their way of life in the future.

3. INVOLVES FACULTY MEMBER PARTICIPATION

If the SPS discussion is to truly offer students an educational experience, then the faculty must also be involved as a partner in the process. Too often, teachers feel that their skills cannot be of use to the student's off-campus learning activities which supplement the classroom environment. If they did, a rich educational experience would be realized for all concerned. As John Dewey noted in EDUCATION AND EXPERIENCE, "Basing education upon personal experience may mean more multiple and more intimate contacts between the mature and immature than ever before, and consequently more, rather than less, guidance by others." 10

4. INCLUDES MULTI-DISCIPLINE OPPORTUNITIES

The structure for participation must include opportunities available to all students regardless of discipline. Many in the academic comunity believe that our traditional methods of looking at problems through academic disciplines and areas of specialization has complicated our attempts to solve the 
energy dilemma.

Effective student participation should include opportunities for interdisciplinary work -- that is, to integrate knowledge around a significant issue such as SPS. Students and faculty from various departments could assemble to determine what elements of their disciplines might shed light on the SPS theme. In addition, the resources of those outside the academic community should be considered: lawyers, government agencies, industry personnel, and representatives from public interest groups and professional associations could offer much assistance to the discussions. 11

\section{PROVIDES INCENTIVES FOR STUDENTS TO PARTICIPATE}

No methodology makes sense in the absense of an understanding of why students should want to participate in the first place. Simply providing opportunity is not adequate to assure that participation will occur. One must identify incentives which motivate students to participate in an educational adventure versus those incentives which motivate general citizen participation.

A few examples of incentives which various methods might offer to students include:

- assuring that student input will be seriously considered by DOE decision-making personnel;

- creating a sense of responsibility within students to "get involved";

- compensating students for their time through such things as course credit, salaries, internships, etc.;

- rewarding the student's self interest through professional or job development; or

- placing student representatives on SPS advisory committees.

Those individuals or groups who would ultimately organize specific methods might have their own ideas on how people are motivated and what will provide incentives for students to participate in the SPS discussion. 


\section{SERVES A FUNCTION TO DISSEMINATE INFORMATION}

DOE will have a primary interest in selecting methods that will be effective in disseminating SPS information to the student community. To create an awareness of SPS issues among diverse elements of the student population, DOE will need to employ a variety of dissemination techniques. To develop an awareness of SPS issues at an early stage, dissemination methods should receive priority attention when the student participation program is initiated.

\section{SERVES A FUNCTION TO FEEDBACK INFORMATION TO DOE}

In addition to disseminating information, DOE has expressed a desire to receive student feedback (in the form of ideas, opinions, papers, etc.) on SPS issues. Those methods which include feedback opportunities would be highlighted after students have a clear understanding of the SPS issues.

\section{CONTRIBUTES TO EFFECTIVE CONFLICT MANAGEMENT}

The key issue we face in terms of effective conflict management is whether we can discover that "win-lose" methods of discussion must be replaced by "win-win" cooperative methods.

Effective management of conflict is not dependent upon a particular participation method, but upon several components necessary to improve the entire structure of information exchange for the purpose of addressing issues. If those holding fundamentally different views about the nature of an issue are to communicate in a meaningful way, then a framework must be created which includes:

- a feeling of trust among the participants and those conducting the SPS study;

- simplifying complex concepts and working towards conmon definition of key terms and concepts;

- distinguishing between facts and value judgements;

- maintaining a policy of openness for all information. The definition 
of openness that is most applicable to the SPS discussion is:

"...the purpose and the content of the process, as well as the schedule for doing it, are described as clearly as possible... it means that planning is done publicly, to the maximum extent possible, because the decisions that are to be made are public business... And it means that written information generated during 12
the planning process is available to all interested participants."

- developing innovative approaches in creating the future. As DOE's SPS Project Officer, Fred Koomanoff, believes, the current advances in technology (to include low, medium and high technologies) are creating numerous new options for society. These options have increased the complexity of our decision making processes, and only through development of new methods to manage these processes can we move with orderly social and political changes for the good of society. 13

Keeping in mind the above criteria, we would now like to present seventeen methods which we believe offer the greatest potential to involve students in a meaningful way in the discussion of the SPS issues.

Following the presentation of these methods, a diagram is offered on page 61 , which attempts to demonstrate how many of the suggested criteria are met by the methods presented. An " 0 " appearing in a column suggests that a primary function of the corresponding method is to satisfy the criterion which it appears under. An " 0 " suggests a secondary function of the method is to satisfy the criterion. An additional column has been included with the criteria to identify those methods which might also be applicable to initiate general citizen participation. Those methods appropria te for general citizen participation are designated with an " $\mathrm{X}$ ". 


\section{METHODS FOR STUDENT PARTICIPATION IN THE SPS DISCUSSION}

The following outline of methods for participation builds on a previous government-financed publication -- EFFECTIVE CITIZEN PARTICIPATION IN TRANSPORTATION PLANNING. ${ }^{12}$ Sponsored by the Department of Transportation (DOT), the work was conducted by Arthur D. Little, Inc. during 18 months in 1975-76. The report serves as an excellent guide for those engaged in organizing or monitoring citizen participation in policy planning. It identifies 37 major participation methods, many of which would be appropriate for the student discussion of SPS issues.

Since the guide is readily available from DOT, we will not duplicate its numerous findings in this report. We will instead comment on those techniques which have the greatest potential for student participation, as well as to outline some methods not considered in the DOT study. The methods are presented in alphabetical order in a standard format to include: description (of the method), enhancing factors, limiting factors, program references, and cost factors.

\section{CLASSROOM ACTIVITIES}

\section{a. Description}

Probably the easiest way to ignite the SPS discussion within a diverse element of the student population is to promote classroom activities around the topic. Projects developed for classroom use could be conducted as individual or group adventures, and would include instructor participation throughout the activity.

Engineering students could conduct an analysis of the cost factors and alternatives. The legal ramifications and international issues would be appropriate material for projects by political science students. The 
many new courses being developed in the area of science and values could examine the questions relevant to land use or microwave effects. Speech students could research the SPS issue as a topic for debate.

Some of the projects might include an element to take them beyond the classroom. Technical or policy papers could be presented to professional and student organizations for publication in appropriate journals and magazines. Students could also elect to present the findings of their projects before regional DOE hearings, which will very likely take place during the SPS planning process.

It would be desirable to produce a guidebook on how to incorporate SPS into the classroom. Such a guide would review the concept and implications of SPS, and include recommendations on how to apply the topic to different courses, regardless of academic discipline.

\section{b. Enhancing factors}

This is a low cost method which carries the potential to heighten the awareness of SPS issues among a broad range of college students. The process allows the students to determine the size and scope of the project to be undertaken. Because of the flexibility of the method, it can be geared to meet the needs of the individual student, or can be undertaken as a group project to encourage cooperation and the exchange of information.

Such a method offers the opportunity to apply classroom theory to a very real and contemporary social issue, which will be attractive to those seeking a "relevant" educational experience.

\section{c. Limiting Factors}

Classroom activities are primarily a means to disseminate information on SPS and to begin a discussion of the issues on campus. There will be little interaction with DOE or industry officials actually engaged in the 
decision-making process on SPS, or with organizations who are not in agreement with DOE's intention.

Because of the large amount of information being generated on the topic of SPS, it may also be difficult for students to acquire current and new information from local library sources. The short time frame within which some course projects are conducted may make it difficult to obtain information from off-campus sources in sufficient time to aid the project.

\section{d. Program References}

The National Science Teachers Association recently completed a series of publications designed to show teachers techniques to include the discussion of energy issues in the normal classroom curriculum. It is our understanding that request for these materials from teachers ran into the millions.

The organizers of Sun Day prepared brief outlines for student activities related to solar energy issues. While not as comprehensive in design as the work by NSTA, these idea fact sheets were extremely effective in promoting student discussions and projects as classroom activities.

The JOURNAL OF AEROSPACE EDUCATION, a monthiy publication of the American Society of Aerospace Education, includes a section in each issue of how to relate various aerospace and aviation concepts into the classroom discussion. These descriptions include a general discussion of the topic, student project ideas, and questions to measure what type of learning takes place.

e. Cost Factors

Compared to other methods, classroom activities involve a low budget. Cost will be related to staff time and research for the guide, as well as its production and distribution. The actual cost of class activities would be minimal and would be absorbed by the individual students. In the case 
of group projects that may involve the purchase of materials, travel, or participation fees, the academic departments may be sources for funding.

\section{CLEARINGHOUSE}

\section{a. Description}

The topic of SPS is generating a large amount of new research and findings that will affect the nature of the discussions and planning process. Since a key a im of the DOE has been to maintain an open flow of information related to the SPS study, it would appear that a clearinghouse could offer a valuable service in the management of the information.

The clearinghouse would maintain an on-going system to collect all reports, publicity, and resource material related to the SPS discussion. Staff personnel associated with the clearinghouse would be responsible for translating technical information and agency plans into terms comprehensible to those who are not technically-oriented.

Management of the clearinghouse could be arranged by a professional staff researcher with clerical support. In addition student interns could assist with data collection and interpretation.

Methods to disseminate and exchange the information collected by the clearinghouse could include some type of newsletter, periodic press releases, and a toll-free telephone hotline.

b. Enhancing Factors

A clearinghouse would represent a tangible, visible commitment on the part of DOE to communicate with all those interested in the SPS topic. It would help ensure that a central location has the responsibility to gather materials from a diverse amount of viewpoints, and that this material would be organized in an understandable format. It would provide a means for all those interested to become acquainted with key individuals involved 
in the discussion and their points of view. It would also provide the DOE with an awareness of the public's interests, perceptions, and concerns.

c. Limiting Factors

While the clearinghouse offers opportunities for the exchange of information, much of it occurs through correspondence or via telephone, thus there is little interaction at the personal level or the opportunity to discuss the origins of diverse opinions.

The staff person in charge of the clearinghouse would have to be knowledgeable enough to evaluate information to be disseminated to insure that misinformation is not communicated. In addition, reproduction and duplication costs could become an expensive item unless a firm policy related to these costs is established at the beginning of the program.

\section{d. Program References}

Clearinghouses have been effectively used in the Model Cities Program, highway planning, and around educational issues. The technique has been growing in use by groups interested in the exchange of information around issues related to "appropriate technology", and as a means for ad hoc citizen groups to cooperate on a specific issue.

\section{e. Cost Factors}

The amount of requests for information and assistance at the clearinghouse will determine the number of staff and support personnel needed. If a hotline is to be part of the clearinghouse, costs include installation of recording service equipment, and toll-free service charges. Other costs include advertising the availability of the clearinghouse service and rental for the facility.

\section{COMPUTER-BASED METHODS}

Student participation through computer-based methods refers to a 
variety of experimental techniques to enhance the participatory process. The application of these technologies offer innovative methods for group communications, goals formation and information exchange. Different types of hardware can be utilized for various aspects of the participatory process. Some of the techniques identified by the DOT study include teleconferencing, polling, gaming and simulations, and interactive computer graphics. As the study indicates, some of the techniques are in the developmental stage, while others are available, but not widely used.

In teleconferencing, participants are geographically dispersed and linked through terminal keyboards, connected to a central computer with some mechanism for the display of information. Participants messages can be sorted, transmitted, or stored for later use. Participants communicate with each other by typing out their messages and reading those of the others. Many of the available programs and the necessary equipment to participate in the experimental programs have developed on university campuses. Polling technology can be used in group situations to indicate immediate responses to statements and concepts through a hand-held console with a response switch. A digital mini-computer collects and stores votes, which are then displayed on an electronic board. This procedure allows all participants equal opportunity to register their vote and to get immediate visual feedback on the opinions of the entire group. Such a system can allow for the discussion of controversial questions without intimidation, and assists in establishing priority interests of the group. Pioneer work on this method has been conducted at MIT on a conmunity dialogue project.

\section{b. Enhancing Factors}

When combined with other participation methods, the computer-based techniques offer the potential to enhance the participatory process. The 
speed and memory capabilities of these techniques are helpful in reaching decisions and analyzing information quickly. Conferencing via computers makes it possible for a geographically diverse group to participate in a discussion and saves travel time and costs. Such innovative methods using computers have a certain appeal to students who are excited about the use and application of this type of technology. As mentioned earlier, much of the research and application of computers is occurring on campuses, which would make them highly accessible to students.

\section{c. Limiting Factors}

The DOT study points out that the use of computers is disliked by many who have visions of an "Orwellian world". The use of computers for participation also raises serious questions on political and ethical issues as to value judgements which are programmed into the data.

Because much of the use of computers requires further evaluation, little is known about the human factors in this type of participation. Those who are in favor of more human interaction may have objections to the dehumanizing implications of using such techniques.

The amount of equipment necessary for some of the computer-based programs may make this process unavailable to many students or student groups. In addition, the process requires the availability of trained programmers and technicians.

\section{d. Program References}

Reference has already been made to the computer-based systems at MIT and the University of Illinois. In addition, the U.S. Office of Emergency Preparedness had utilized such systems for management studies. At the University of Michigan, the CONFER system has been developed for several applications, including meetings, seminars and inter-university communication. 
A number of small conferences, sponsored by foundations and private groups have focused on topics ranging from world $\mathrm{cl}$ imate changes to technology transfer.

\section{e. Cost Factors}

Cost factors related to computer-based technology will depend on the type of system and program selected for the situation under study.

\section{FIELD TRIPS}

\section{a. Description}

Field trips related to SPS could be a practical means to establish communication and understanding among those who hold differing views on the related issues. Field trips provide a common base of experience for all those involved in a discussion of SPS issues. Creating this common base is extremely critical when dealing with a topic like SPS which involves a highly technical language, because the same word may create different images within various participants.

While no construction of a satellite is currently taking place, field trips could be organized to potential sites for the antennas that would receive microwaves from an SPS. With knowledgeable industry, utility, and enviromental officals, a discussion could take place around issues related to the business of site location and its implications. Another visitation might involve a trip to the NASA/Kennedy Space Center to discuss the environmental impact of the numerous launches that would be required to send materials to the in-space construction site. Other field trips could include visitations to aerospace companies who may be interested in building SPS hardware, or trips to a radio observatory to talk with scientists about microwave testing.

b. Enhancing Factors 
Field trips present an opportunity to more clearly visualize the circumstances related to the purpose of the visit. The trips will expose the visitors to a wider range of personnel who work with the area under discussion, which can be helpful in clarifying issues.

\section{c. Limiting Factors}

Locations for visitation may be limited due to the nature of the issue. For example, students located in the Midwest would have difficulty in making a visit to the Kennedy Space Center or to a desert antenna site. The availability of manufacturers working on SPS research may also be confined to certain areas.

It may also be difficult to ga in an accurate impression of what will really occur at any site since the tour guides will probably want to present a favorable impression and may neglect to mention negative features connected with their work.

d. Program References

The recently-completed National Coal Policy Project, conducted by the Center for Strategic and International Studies at Georgetown University, made extensive use of field trips. The Project's final report, WHERE WE AGREE, catalogs the sites and purposes of the numerous trips that were made by the participants.

The Forum has also had several experiences with field trips, especially in conjunction with national conferences. An evaluation survey following a conference and the field trip the Forum sponsored at the NASA/Ames Research Center, reported that $81 \%$ of the participants felt that the visitation was a necessary element of the conference program.

\section{e. Cost Factors}

The primary cost concerns travel arrangements and related logistic 
requirements.

\section{LECTURE SERIES AND PRESENTATIONS}

\section{a. Description}

Presenting lectures on college campuses around the topic of SPS could be arranged around two concepts: locally developed series or a nationally-sponsored tour.

The local series concept would encourage students and faculty at a college to arrange for a series of lectures either on specific aspects of SPS or on various energy alternatives to include SPS. The local organizers would seek out qualified speakers from within their own campus to include presentations by faculty, students, organization representatives, or local goverment and industry representatives. Individual presentations could be sponsored or perhaps debates among those with opposing views. To add a consistent element to the organization of the program on different campuses, it may be appropriate for DOE to recommend a list of topics that should be covered to insure that all aspects of SPS are described.

An alternative to the local lecture series is the idea of having a traveling "tour" or "energy concert," which would include the presentation of the SPS roption. This concept would also have numerous variations -- one "visible scientist" presenting a comprehensive lecture on the pros and cons of SPS; a traveling debate; or a traveling panel to make presentations on different college lecture programs/convocations, or special events could be arranged.

\section{b. Enhancing Factors}

If publicized well in advance, the lecture concept can be an effective method to spread awareness of the SPS option among a large segment of the student community. As one program director commented, "It (SPS) has enough 
space-Star Wars feel to it to gain interest among students." The increasing concern of microwave effects and the popularity of the book, THE ZAPPING OF AMERICA could also help guarantee an interested audience. An advantage of a local series centers on having students involved in the organization and drawing on resource talent from their geographic area. An advantage of the traveling presentation would be that a consistent program would be seen by students at various colleges.

\section{c. Limiting Factors}

Unless institutions involved in the tour concept were able to pay an honorarium or travel costs, this could be an expensive method. Because of the relatively recent emergence of SPS as an energy option, it may be difficult to find a sufficient number of qualified speakers to either take part in the local lecture series or in the national tour. In addition, these types of programs are rather short in length and may not present an adequate opportunity to discuss a complex topic such as SPS. Finally, because of the large number of events available on campus, SPS may not attract a sufficient audience to justify the time of the speakers.

\section{d. Program References}

Virtually every college and university sponsor some form of lecture series. The AMAX Foundation recently funded a series on the "Public Understanding of Science" at the Colorado School of Mines, with many of the topics concentrating on energy themes. It is not at all unusual to see crowds ranging from 500 to 5000 for the public lecture series sponsored at the annual meetings of the American Association for the Advancement of Science. In addition, many professional societies and public interest groups mainta in "speakers bureaus" for resource personnel qualified to speak in their areas of interest. 


\section{e. Cost Factors}

A common cost element for all lecture programs involves publicity and advertising expenses. Regardless of who has to pay, there is also the consideration of travel costs and possible honoraria.

\section{MEETINGS AND CONFERENCES}

\section{a. Description}

The use of meetings and conferences is among the most often used techniques to disseminate and exchange information, and as a method to respond to public programs and issues. In a survey of student programs conducted by the Forum and the Science Education Office of the AAAS, 46 of the 82 respondents mentioned that they offered meetings as services to their members. In a survey by the Center for Research on Utilization of Scientific Knowledge (CRUSK) at the University of Michigan, conferences were the most often used method to disseminate technology assessment studies.

Conferences may vary in length from one day to several weeks. Their format will be determined by the purpose of the meeting and by the desired outcomes from the participants. Most meetings include some type of large group session for the presentation of general information or for presentations by major speakers. To focus on specific issues or to encourage interactions among participants, smaller working groups are held.

Conferences may also be conducted in conjunction with other participation methods. In large scale operations such as the Annual Meeting of the AAAS, techniques such as surveys, satellite communication, Congressional hearings, workshops, and public lectures have been demonstrated. The Committe for the Future, a Washington, D.C.-based organization, has developed a conference format called SYNCON (for synergistic convergence), which calls for extensive integration of live television and video programing, 
the construction of a large wheel divided by collapsable walls to facilitate the process, telephone lines to resource centers and libraries, and in some cases, the production of a nightly news program.

Well-produced conferences with well-defined objectives can of ten capture the interest of the press who can be usefur in further disseminating information. The development of press packets and special press briefings with name speakers can help develop a cooperative relationship with reporters.

b. Enhancing Factors

Meetings and conferences can provide an opportunity to present complex information and issues in lay language and to receive immediate feedback from participants. They provide an opportunity to present and understand conflicting points of view and to pursue the basis for these differences at a very personal and informal level.

Meeting opportunities can allow goverment agency personnel to get out from behind the desk and discover what people in the field are really thinking. At the same time, this may provide an opportunity for participants to interact and exchange ideas with speakers and experts from outside their normal circle of experience.

Since conferences can easily be held on college campuses, the events offer many opportunities to include exposure to numerous experts, the chance to present and test their ideas with a larger audience, exposure to new information, and the chance to become part of events which may develop from the conference.

c. Limiting Factors

While the conference is often the most utilized technique to promote public participation, it is not necessarily the most effective. Too many conferences are poorly managed and have inadequate objectives. This can 
result in feelings of $i 11$-will among participants and damage relationships and the credibility of the host.

Some writers feel that too much importance is placed on what is said by speakers and experts at conferences. The trickle-down theory, which assumes that all knowledge and insight occurs at the top, is in direct conflict with the demands for citizen participation in the first place.

Unless an agenda for follow-on activities results from the conferences, it can be argued that the expense involved cannot be justified for a one-time event. Conferences, because of the extensive amount of planning involved, are expensive undertakings. In addition to costs to the host institution, travel funds are of ten necessary for the participants .- an item which is being rapidly and severely cut by organizations, institutions, and government agencies.

Finally, because of other academic commitments which students have, their participation in conferences may be limited. No matter how important the conference is or the caliber of presentations to be made there, many instructors will refuse to waive attendance requirements for their courses so that students can participate in outside events.

\section{d. Program References}

Information on the organization and management of conferences is available from numerous sources. Evaluations of their effectiveness are less available. The Forum has a reference library of numerous proceedings from DOE-sponsored energy conferences, which includes ideas on formats and discussion topics.

One organization that receives consistently high praises for their use of conferences as a participation technique is the League of Women Voters. During the past five years they have sponsored a very active 
energy awareness program for their members and have gained considerable insight as to when and how to use conferences. The League is in the process of writing a report and evaluation of a $\$ 200,000$ energy education project they conducted under a DOE grant.

\section{e. Cost Factors}

The costs related to this technique are dependent on the degree of complexity, the number of participants to be involved, the amount of advanced-planning time required, the location, and the number of days the conference will extend. It can be an expensive undertaking which includes costs related to travel, facilities, publicity, equipment rental, staff support, room and board and mailings.

\section{MOBILE PRESENTATIONS}

\section{a. Description}

Taking SPS on the road with a mobile presentation could attract interest among representatives of the campus community, and be designed to both disseminate information and collect feedback.

This concept would involve the use of a display set up from modules or crates and carried from campus to campus in a small van or truck. The display would be such that it could be set up in classrooms, at conferences, or even outdoors in the middle of campus. The display would explain the concept of SPS with models, diagrams, and charts. The pros and cons of this technology could be presented through the use of various media.

The person driving this display would also be trained as a spokesperson on SPS and be qualified to answer student questions and clarify concepts. This person could also facilitate discussions, moderate debates, and conduct interviews among the student population.

To ga in feedback from the community, a survey could be developed 
to assess student opinions on SPS and other energy questions. The mobile unit could also provide materials for students to keep, as well as serve as a collection point for student-written papers and projects relevant to SPS.

\section{b. Enhancing Factors}

The head of NASA's Education Office, Dr. Fred Tuttle, believes that nothing can compare with the effectiveness of the mobile concept, both in terms of cost and outcomes. Such presentations can offer a pleasant alternative when used to supplement classroom activities, and the presence of an SPS display in the middle of campus would Tikely draw the interest of a diverse group of students. If designed as a unique and creative package, the mobile unit can generate its own publicity and thus bring attention to the issues of SPS.

Past users of mobile units have demonstrated that they are very effective in establishing direct contacts with very large audiences.

c. Limiting Factors

The mobile concept has its limitations as a participatory mechanism. While feedback can be generated thorugh surveys, the collection of papers, and through recording student comments on video tape, it does not allow for significant interaction with those in decision-making positions. In addition, great care would have to be taken in the design of the display to ensure that the SPS concept would not necessarily be promoted as a technology that has already received the go ahead.

\section{d. Program References}

The NASA "Spacemobile" is probably the best example of a successful mobile program that has a long track record to evaluate. In existence for 17 years, NASA estimates that over one and a half million people come in contact with the Spacemobile each year. This does not include the millions 
who see the display thraugh commercial and educational television. The Spacemobile concept employs teachers as the drivers to set up and discuss the displays in conferences and classrooms.

The Committee for the Future conducted a caravan concept around the theme of Project Independence in 1975. A traveling exhibit included a 20 minute video tape explaining energy independence, which was followed with a panel presentation of community leaders. To include a participatory element, citizens were asked to send their "message to Washington," which included the video recording of their comments for use in a documentary that was presented at a national conference and eventually to Congressmen and representatives of Federal agencies.

e. Cost Factors

A mobile presentation will require a paid driver and living expenses. The van will, of course, require fuel expenses, which could become expensive if this unit is to travel around the country. Other costs will be associated with the design and construction of the display, and in the development of materials to be distributed when presentations are made.

\section{PROBLEM/POSSIBILITY INSTITUTES AND NETWORKS}

\section{a. Description}

The concept of Problem/Possibility Institutes has been developed through the writings of Robert Theobald, a futurist and socioeconomist. Originally introduced in TEG 1994, a book he co-authored, the problem/ possibility $(P / P)$ concept suggests that social issues have to be approached through new directions of study and analysis.

In the case of SPS, a P/P Institute would be convened. Through existing communications networks, an attempt would be made to identify many types of people who have achieved an understanding of energy issues and are 
familiar with the SPS concept. These people would be invited to a meeting and would be challenged to clarify questions and issues related to SPS. Through a P/P Focuser, a list would be made of areas of agreement and disagreement to include reasons for the beliefs.

The Focuser would show why differences on SPS can't be solved within present patterns of thinking. The understanding of the problem is essential to the possibility of action because it creates the energy which will permit people to change their values and actions. In order for the Focuser to be used at different levels and among different groups, it could be developed into several types of information packets: written, audio, and video.

The Focuser would be distributed to existing organizations and groups for discussion and feedback. The concept works best if conducted within small, locally-organized groups. These local groups would further refine the questions raised in the Focuser and discuss other implications of SPS. While these local meetings were being held, student interns for the project would research new data, ideas, and breakthroughs for discussion at the next Institute.

The feedback from the local groups would take two forms: responses to a common questionnaire completed both before and after the local session, and solicitations of what they think DOE should do with the SPS program.

Each local group would then designate one or two representatives to attend a national Institute in Washington, D.C. The Institute would then review the initial findings, the clarifications and questions proposed by local groups, and come up with recommendations for DOE.

b. Enhancing Factors

The $p / p$ concept recognizes that all participants have equal status throughout the process and that all skills are necessary for successful 
discussion. Since monetary compensation is not highlighted, participants tend to be those who are truly committed to the creation of new levels of understanding.

The process also assumes that it is best to work with the most competent people rather than those who are not, and that some people will al ways know more about a certain subject than others. Working with the most competent participants will el iminate those who are unknowledgeable on the issues involved. The process also assumes that the characters will al ter continuously due to changing interest patterns: and ability to keep up with the subject. This helps guarantee that many types of people will be involved in the discussion and that no one group will dominate the process.

\section{c. Limiting Factors}

Because $p / p$ calls for new types of understanding about the nature of our society, it is incompatable with the current disciplinary organization of knowledge used in colleges and universities and the problem orientation used by most decision-makers. It may therefore be difficult to gain the cooperation of those who view the process as a threat to their authority and level of responsibility.

The stress placed on participation by the most competent also places the fear in some that the process is another attempt to create governance by the intellectual elite.

\section{d. Program References}

The $p / p$ approach has been demonstrated as a technique to discuss issues related to education, health care, a guaranteed income, and ecology. The Northwest Regional Foundation, a Spokane-based organization with which Theobald is associated, has been the most active proponent of the concept. e. Cost Factors 
Al though individual monetary compensation is not encouraged, some type of seed funding would be necessary for the meetings held at the local level. The national Institute would require those expenses normally associated with conferences. The concept attempts to make maximum use of the ongoing educational process of institutions to provide funding support.

\section{PUBLIC HEARINGS}

\section{a. Description}

Because they have been required at various levels of governmental decision-making for many years, public hearings have a long history as a citizen participation technique.

The procedures for hearings are generally set by law and are fairly formal compared to other procedures. During the past five years, regional hearings have been held on numerous energy issues. Usually the agency or division sponsoring the hearing presents a plan or proposal, followed by the testimony of individuals who have asked to be recognized. In most cases, the hearings are open to all interested in attending, complete transcripts are recorded, and the proceedings made available upon request.

\section{b. Enhancing Factors}

Hearings are designed to let everyone be heard and to have their comments be officially placed "on record." Well-prepared presentations can make forceful impressions on those conducting the hearings. As a device to involve students, hearings offer an opportunity to become directly involved in the agency's decision-making process. Papers or projects being developed by the student in the classroom may be appropriate as evidence and background material to be presented at a hearing. In addition, students attending hearings will be exposed to a wide range of viewpoints and information.

c. Limiting Factors 
The hearings process is primarily a one-way method of communication, and many critics contend that the information is never used in a meaningful way. There are those who see hearings as fulfilling a minimum commitment to involve citizens and that decisions have usually been made prior to the request for this input.

Critics also contend that hearings are poorly publicized with little advanced preparation time given. When citizens do find that a hearing is to take place, it may occur during inconvenient hours. Students, once again, could have difficulty leaving scheduled classes to participate in hearings held during class hours.

Many hearings involve emotional issues which can produce irrational presentations. If a large number of hostile witnesses request time to speak, it is not unlikely that shouting matches will develop.

\section{d. Program References}

One writer estimates that the number of hearings held each year runs in the tens of thousands. A recent example that should be studied by the SPS management team involved the regional hearings on the Domestic Policy Review Committee on Solar Energy. Proceedings from the ten regional hearings and a final report are now available from the Consumer Outreach office at DOE.

\section{e. Costs Involved}

Costs for hearings include staff, publicity, postage and mail list purchases, meeting facilities, publication of proceedings, and travel.

\section{RACIO PROGRAMS AND NETWORKS}

\section{a. Description}

Primarily to be used as part of the Student Information Program, use of radio as a technique deserves a few additional comments.

Unless used as part of a call-in type program, radio is essentially 
an information dissemination technique. As a method to disseminate information on SPS, it has the potential to reach an audience of millions.

Announcements on radio could be used to alert students to involvement opportunities in various SPS discussion programs. At another extreme, SPS could be the topic of a radio talk show or lecture presentation. A format that might be appealing to the student audience would include a program on SPS that would blend brief comments and discussion on the topic with appropriate music.

b. Enhancing Factors

The use of radio as a medium to discuss science issues appears to be on the increase. Program formats currently in use include two minute, five minute, twenty minute, and one hour features. Programs are inexpensive to produce, and non-commercial stations welcome pre-produced tapes, which cut down on their costs.

While we have not discovered any surveys on how often students listen to these types of programs, the National Educational Advertising Service survey did have figures available on campus radio listening patterns in general. According to the survey, of the students having a radio station on campus, $13 \%$ listen to it daily, and $10 \%$ listen to it at least 3 times a week. It would seem that if advertised, an innovative SPS radio production would find a sizeable audience through these stations.

The American Chemical Society, which produces a weekly radio package on science issues has claimed an audience of six to eight million. While there are no breakdowns on how many of these are students, it would seem safe to assume that this network is worth exploring.

c. Limiting Factors

As mentioned above, unless used in conjunction with a radio call-in 
format, these programs are primarily a one-way method to communicate. In addition, most people listen to radio while in the process of some other activity. Trying to explain something as complex as SPS while competing for the student's attention may prove difficult.

\section{d. Program References}

The American Association for the Advancement of Science recently launched a radio program called "Focus." The 30 minute tapes discuss a wide range of science activities and are distributed to 200 non-commercial stations on a complimentary basis.

Eli Productions, an independent media production company, provides two science programs called "Science Scenes." One of these is in a 5 minute format, the other, is 20 minutes.

e. Cost Factors

Cost factors related to radio includes program production costs, staff support, postage for distribution, and research activities. The AAAS reports that each 30 minute tape for the "Focus" series costs $\$ 900$ to produce.

\section{SATELLITE COMMUNICATIONS}

a. Description

While communications satellites have been extensively used by commercial news organizations for many years, the availability of this technology to national organizations and universities is rather recent. The particular satellite that could be useful as a tool for the SPS discussion is NASA's Communication Technology Satellite (CTS), a technology developed in cooperation with the Canadian government.

The CTS has the capability to link geographically dispersed groups 
with two-way color video and audio cormunication. One group originates the program from a location that has the facilities to beam a message via satellite to a group in another part of the country where the message is received and viewed through television monitors. The two groups then meet for face-to-face dialogue through the monitors.

Listed as a demonstration project, the CTS can be utilized at some eight universities around the country, thirty Veterans Administration Hospitals, and through a mobile unit equipped with complete broadcast facilities. Approximately 28 experiments are currently being conducted to apply this technology to educational purposes.

\section{b. Enhancing Factors}

The CTS offers savings in terms of travel time and expenses. It allows individuals to "attend" meetings and programs without traveling across the country causing missed work or class time.

In many cases it offers the advantage for key decision-makers to meet with audiences not normally involved in planning discussions due to geographical limitations. This exposes the decision-maker to new points of view and presents an opportunity for the audience to become more active in the planning process.

This is another method that can be combined in a program package with other participation techniques. A CTS presentation can be part of a conference, a lecture series, or in classroom activities. Because of the use of recording equipment to facilitate the process, documentaries and information packets can be produced on video tape for later distribution.

\section{c. Limiting Factors}

While savings of travel time and expenses are realized with CTS programs, the method does require the use of sophisticated television 
equipment which carry other types of costs. To justify this type of expense, the program must be well organized and produced with clearly stated objectives. The organizers may also be called on to justify the use of the CTS versus other formats such as conference calls or more traditional presentation techniques.

Since the system is new for educational users, there are few "experts" who know how to apply this technique in the most effective manner. In addition, there is an availability factor to consider since there are numerous experiments competing for 1 imited "air time."

The experimental nature of the technology also means that there are some "bugs" in the system and occasionally equipment Breakdowns may occur during the program. As of this writing, the life expectancy of the CTS appears to be in doubt and its availability throughout the remainder of the SPS study is subject to many questions.

\section{d. Program References}

NASA currently has contracted 28 experimenters to develop programming with the CTS capabilities. The evaluations of some of these programs are just now beginning to be published.

The Forum has sponsored two programs utilizing the CTS. In April of 1977 a discussion was held with the Director of the National Institutes of Health on the topic of recombinant DNA molecule research. A group of 25 students were brought to the studio of the National Library of Medicine to meet in person with the Director. Conducted in a talk-show format, this discussion was broadcast live, via the CTS, to another group of students who were gathered at the NASA/Ames Research Center in Moffett Field, California. The California students were able to see and hear the presentation and take an active part in the question and answer session. 
The second Forum CTS program took place in conjunction with the Annual Meeting of the AAAS in February, 1978 in Washington, D.C. This session featured a panel discussion on the Search for Extraterrestrial Intelligence and was aga in broadcast to the Ames Research Center. A crowd of 350 participated in the program on the Washington end while 250 gathered at Ames. One of the panelists gave his presentation from the Ames location.

\section{e. Cost Factors}

To be produced for the greatest benefit, use of the CTS requires extensive advance preparation and cooperation between many characters. Facilities for holding the program must meet certain physical requirements due to numerous technical considerations. If some of these conditions are not readily available, then additional expense is involved in obtaining certain types of equipment.

The equipment rental costs are the most expensive item to consider, as well as technically-trained individuals to operate the hardware. In addition, to produce a documentary or materials for later use, the purchase of video tape and editing facilities will be required.

If the program can gain sponsorship under an existing experimenter, it is possible to encounter few direct expenses. However, it is our understanding that some of these experiments have been concluded and new pricing policies will soon be implemented.

\section{STUDENT DEBATES}

\section{a. Description}

A method with high potential to include non-technical students in the SPS discussion involves campus-sponsored debates. An event which could grow out of a classroom activity, an SPS debate might be co-sponsored by an appropriate academic department and the student activities center. A sug- 
gested debate topic might be -- Resolved: The United States should commit itself to the production and implementation of a Satellite Power system. Traditionally, college debaters are requested to brief themselves on various points of view, and to be prepared to argue all positions of an issue. However, since the opportunity to discuss SPS may appeal to students not pursuing formal debate instruction, participants would only have to prepare a presentation for the view they advocate.

In addition to organizing this method as a local activity, it also has potential as a national event. Each year the American Forensic Association selects a topic to be addressed by campus debate teams through a national competition. The SPS concept could be recommended to the Association as the debate topic for the 1979-1980 academic year.

Reports and papers that have been developed throughout the SPS study would serve as excellent research materials to prepare the students for the debates. Of particular benefit would be a bibliography and list of organizations active in the SPS discussion.

b. Enhancing Factors

Debates serve as an excellent method to encourage the non-science oriented student to become active in the SPS discussion. The nature of the method requires that the students prepare themselves thoroughly on all points of view if they are to defend their position.

If an effective publicity campaign is incorporated into planning the debate, a substantial audience might be encouraged to observe and learn from the event. Debates could also be conducted in conjunction with other methods such as conferences, a lecture series, or on radio or television programs.

\section{c. Limiting Factors}

Student debates are primarily a means to encourage campus awareness of SPS issues and information. There would be little interaction with DOE 
decision-makers.

Because of the highly technical and dynamic nature of SPS issues, it may be difficult for the judges to verify certain arguments or disputed information brought forward during the debates.

d. Program References

As mentioned above, the American Forensic Association (AFA) has substantial experience in managing campus debates as part of their on-going activities. The college-level AFA topic for 1978-79 concerns guaranteed federal employment for all U.S. citizens, while the high school topic addresses the national energy policy.

Numerous environmental organizations have sponsored local debates around topics such as genetic research, nuclear power, and the SST. National public interest groups and trade associations are called upon for materials for these local debates.

e. Cost Factors

Debates are an inexpensive participation method. Most research materials can be obtained from the 1ibrary, government agencies, and industry at little or no cost. A national debate involves travel and lodging costs, but these are usually provided through the college.

\section{STUDENT INFORMATION PROGRAMS}

a. Description

Student Information Programs include techniques to be used throughout the entire SPS study project, rather than a one-time event. The programs would be designed to provide students with general information about the study and its progress. They would include the dissemination of information of both technical data and social issues. In many cases, this program will be an integral component of other techniques such as conferences, internships, 
clearinghouse activities, etc.

Student Information Programs can employ a variety of techniques:

- press releases to the campus press (according to the National Education Advertising Service, 92\% of college students read their campus papers);

- direct mail distribution of educational materials to students, organizations, and faculty members. These materials may be presented in the format of newsletters, editorials, brochures, etc.;

- displays, slide presentations, films, video tapes, and other visual materials for use by local students and major presentations; and,

- responses to inquiries from students and faculty.

b. Enhancing Factors

With a relatively new subject such as SPS, a we11-produced Student Information Program can provide information fast and effectively, particularly when technical information must be translated into understandable terms. The combinations of techniques makes it possible to reach a large student audience with accurate information about SPS. This program is almost always essential to the success of other techniques.

\section{c. Limiting Factors}

A Student Information Program is usually a one-way method of communication and does not allow for student interaction with decision-makers. If the information does not remain balanced and non-comittal to a decision on SPS, the credibility of all those involved will suffer. Also, if students are bombarded with publicity, their suspicion about DOE's motivations may be aroused. A good example of this can be seen in the over-abundance of nuclear energy material that was distributed in California prior to the vote on Proposition 15.

\section{d. Program References}

The techniques for a Student Information Program are used by virtually 
all national, state, and local student organizations in planning events and participation.

\section{e. Cost Factors}

Student Information Programs can be expensive, depending on how elaborate the program becomes. Costs include preparation of mail lists, printing materials, postage, and the accompanying staff effort.

\section{STUDENT INTERNSHIPS}

a. Description

The technique of Student Internships is based on the belief that students have an enormous amount of talent and idealism that should be nurtured and applied to contemporary problems and issues. Their involvement in applied internship programs brings the values and interests of young people to bear on policy planning and decision-making.

From another perspective, internship opportunities give students "hands-on" experience with issues they normally only encounter through a textbook vision. Their experience as interns often exposes circumstances and realities that may not be discussed in the classroom.

To be effective for all parties concerned, the internship must include significant work assigments and go beyond clerical and "go-for" tasks. The increase in the number of internship programs being offered by colleges, government agencies, Congress, and national organizations, testifies to their popularity with students and benefit to the host institution.

It should be feasible to have a student intern assigned to each and every study component of the SPS project. This would significantly involve students and their ideas throughout the project, could help provide opportunities to receive academic credit for off-campus work, provide positions for student employment, and provide valuable assistance in areas 
of research, management, and program development.

\section{b. Enhancing Factors}

Student internships insure the planning agency the benefit of student thinking and points-of-view in all phases of study. As representatives of the campus community, the students can share their impressions of current values and interests of fellow students, and advise on methods to include students in the participation process.

The interns could serve as a test population for participation techniques before they are presented to the campus, as well as serve as a liason between students and decision-makers. The student intern could be assigned specific tasks and responsibilities which can release the professional staff to concentrate on more technical aspects of the process.

\section{c. Limiting Factors}

Use of student interns carries the potential for coopting the students involved. Because of their inexperience, they may be subjected to conflicting loyalties and role confusion. Their in-depth exposure to the issues under study may push them to adopt agency objectives and make it appear that they have sold-out to the "establishment."

There is no guarantee that the student selected for the internship will represent the views of a broad range of students. A student more concerned with personal advancement and ful1-time employment may do or say anything to be seen in a favorable light by the host institution. This could cause resentment by the rest of the student community who do not feel their views are being represented.

Finally, a Student Internship Program requires an investment of time from the host agency in defining tasks for the students, supervising their work, and instructing them in overall methods of operation. Without 
a comitment to the concept of an internship, the students will not be engaged in meaningful work. leading to frustration with the project and creating negative feelings toward the possibility for student participation.

\section{d. Program References}

The Viking Internship Program, sponsored by NASA, is a current example of the concept applied to a circumstance similar to SPS. The program utilized interns as partners with Viking investigators throughout a two-year period. The experience received high marks from both the students involved and the scientists who supervised their work. As further evidence that good cooperative relationships were established, when the Viking Project Team won a monetary award from the American Association for the Advancement of Science, they donated the funds to student scholarships.

The popularity of internships can also be seen by the existence of two organizations* in Washington, D.C. Which coordinate over 500 internship programs around the country.

\section{e. Cost Factors}

The costs of student internships depend on the number of positions to be created and the salary level to be established. Other expenses include training and supervision time on the part of the agency, and a mechanism to announce availability of the internships.

(AUTHOR'S NOTE: The Forum did employ a student intern during the first two months of this study who assisted with research and the development of participation techniques. Our experience with the intern was positive, and we believe we gained insights to improve future relationships of this nature. We will be happy to share these insights and comments with other members of the study team interested in establishing internships for study projects throughout the SPS discussion.)

* The National Center for Public Service Internship Programs and the Washington Center for Learning Al ternatives 


\section{SURVEYS AND QUEST IONNAIRES}

Surveys are an inexpensive method to gather information, attitudes, and opinions from a large number of people, as well as to assess citizens' knowledge of the topic under consideration. Other than talking to every citizen, it is the only technique which is capable of being statistically representative of all citizens. In an era of rapid change, it is considered an important tool to aid the planning process.

If the survey is to be an effective technique for student participation, it must be designed with a thorough understanding of its many complex components. During a time when so much emphasis is placed on the results of polls and national surveys, there is a great temptation to jump on the band wagon and create a survey for every issue of public concern. Armed with facts and figures from surveys, it is not uncommon for opposing points of view to interpret the same data as support for their ideas.

The previously-mentioned DOT study presents a rather complete analys is of how to effectively utilize surveys for citizen participation. Primary considerations in applying this technique include knowing when to survey, how to design a quesionnaire, how to determine the scope of the questions, how many people to survey, how to collect the data, when to pretest, how to edit the data, what to do with the data, and finally, how to schedule a survey.

\section{b. Enhancing Factors}

The biggest advantage to a properly-designed survey is its ability to represent the views of specific populations. Respondents are also more likely to express their true feelings through a technique which guarantees their anonyity. The survey also allows for the collection of a greater amount of detailed information than is possible through other techniques such as hearings or conferences. 
Surveys can also be used in conjunction with other participation techniques, which helps planners understand citizen views from several levels. In reference to the SPS project, it can be an effective tool to monitor changes in attitudes and perceptions throughout the study period.

In the majority of cases, surveys are highly cost-effective in terms of gathering information for their costs.

\section{c. Limiting Factors}

While the sponsors of a survey are truiy interested in receiving "objective" information on the public's view, this technique does not highlight interaction or involvement in the on-going discussion. New facts, ideas, and expectations cannot be easily incorporated into the survey design. There also appear to be trends that people are becoming "surveyed-out" because of the increasing frequency that they are asked to participate in this method. Often, they are never informed of the results of their input and are left with the impression that they were merely a statistic for someone else's project.

Because the design of the survey is not an interactive process, the participants are forced into responding to questions that they may not comprehend or understand how these relate to the overall topic under consideration.

\section{d. Program References}

As the DOT study notes, surveys have been the mainstay of commercial market research for years. Their use in the public sector is on the increase to gather information on transportation, health, education, urban planning, social service studies, and, of course, political elections.

e. Cost Factors

The cost factors related to surveys will be determined by the type 
size, length, location, time, personnel required, and use of computers. The most expensive surveys are those based on in-depth, personal interviews, while the least expensive are those based on short mail questionnaires.

\section{TELELECTURES}

a. Description

Telelectures involve the presentation of information through a combination of slides and the telephone. Arrangements are made to have a group meet in a room which has access to a telephorle hooked into a speaker or conference-call amplifier. At a designated time, a speaker--generally from another city -- will call the group to present a lecture, accompanied by slides which have been sent to the group in advance. The lecture will usually last from twenty to forty-five minutes, followed by a question-andanswer session. A transcript and/or audio tape recording can be made of the lecture and kept on file with the slides, which remain with the sponsoring group.

\section{b. Enhancing Factors}

The telelecture format offers an inexpensive alternative to the more elaborate use of interaction with satellites. It features the same savings in terms of travel cost and time for the speaker, but requires little additional equipment. The method is especially useful to the classroom situation for both small and large groups of students. Because the sponsoring group is generally allowed to keep the slides, an addition can be made to the resource library, and since transcripts can be made of the lecture, the program can be duplicated for use by other local groups.

\section{c. Limiting Factors}

Since there is no visual contact with the audience, the telelecture could become boring if the speaker is unable to hold their imaginations. 
A boring speaker could easily end up talking to an audience who is more interested in reading magazines or completing an assigmment for the next class. If a test of the phone link has not been made in advance, the whole program could suffer because of poor audio connections. Taking the time to make the necessary adjustments could interfere with limited class time and generally get things off to a bad start.

\section{d. Program References}

The NASA/Ames Research Center has sponsored a very successful telelecture program on the theme of the Viking Mission. Arranged by the Office of Education, the program included a resource pool of several speakers who could discuss various aspects of the Mission. The Forum encouraged its network of students to make use of the program, and feedback to our office has been highly favorable.

\section{e. Cost Factors}

The telelecture format requries a slide projector and screen, a meeting facility, a mechanism to amplify the speaker's voice either through an overhead speaker system or conference-call device. If the conference-call equipment is needed, there will be an installation fee ranging from $\$ 75$ to $\$ 125$. Several of the students associated with the Forum were able to acquire this equipment for a one-time use as a donation from the phone company.

\section{VIDEOTAPE}

\section{a. Description}

While the authors have been unable to document the number of campuses with video capabilities, most communication experts contend that the trend for acquisition of video equipment is increasing. Videotapes have become a useful educational tool, finding acceptance as a mechanism to 
disseminate scientific information.

"Most scientific applications of videotape have been to the recording of meetings, lectures, presentations, with the stress placed on those in which visual communication has played an important role."14

Once information has been recorded on tape, numerous applications for the content become available. The tape can be viewed in the classroom, as part of a conference presentation, placed on file with a video library, or played on local commercial and cable television stations.

As a method to involve students in the discussion of SPS, videotape programs could be utilized as both an information dissemination technique and as a feedback mechanism. A one-half to one hour tape could be produced to explain basic SPS information through a combination of music, speakers, artists' conceptions, etc. Such a tape could conceivably be contracted out to a university as a class project for television majors.

Students might also wish to send a "message to Washington" explaining their thoughts on SPS for DOE decision-makers. Such a tape could include formal presentations, informal interview with students, or visual presentations of campus attitude surveys on SPS.

\section{b. Enhancing Factors}

College students have grown up with a steady diet of television and have become accustomed to acquiring knowledge through this medium. According to a study by Advanced Systems, Incorporated, "learning time with video is five times faster than student reading comprehension and three times faster than the traditional classroom lecture." 15

Video presentations can bring outstanding authorities to a large number of campuses at a tremendous savings of travel time and money.

As stated above, this method offers great flexibility in terms of end 
use and allows the students involved to make such decisions based on their needs and desires.

\section{c. Limiting Factors}

Not all video programs necessarily meet their educational objectives. Inadequate planning or poor editing can produce a video bore. Those preparing the tape must either be well-trained in their craft or else be supervised by experts.

Some teachers may not be enthusiastic about video presentations if they see it as a threat or competition to their authority. For this reason, it is advisable to gain the participation of the instructor when a tape is to be presented before a particular class.

A background tape on SPS could run into difficulty because of format considerations -- black-and-white versus color, tape width, or cassette versus reel-to-reel. When it comes to what type of video equipment colleges own, there appears to be no such thing as standard equipment.

\section{d. Program References}

The Tape Library of Advanced Systems, Incorporated currently holds over 2,000 tapes addressing most professional disciplines. ASI has had extensive experience in the preparation of educational tapes for both colleges and industries.

A recent publication from the Center for Advanced Engineering Study at MIT called, VIDEO AT MIT: A PROGRESS REPORT, is another helpful program reference. The document reports on a wide range of video applications to the traditional learning process.

e. Cost Factors

For the purposes of the SPS Study, programs utilizing video tape should be aimed at those institutions which already have equipment and 
facilities. Costs for production include personnel, equipment or studio rental, blank tapes, and distribution of the end product. If produced as a class project, many of these costs might be absorbed by the institution. If the tape is to be utilized as part of a class presentation or in conjunction with a conference, appropriate viewing equipment might have to be rented. 
METHODS AND CRITERIA

EVALUATION

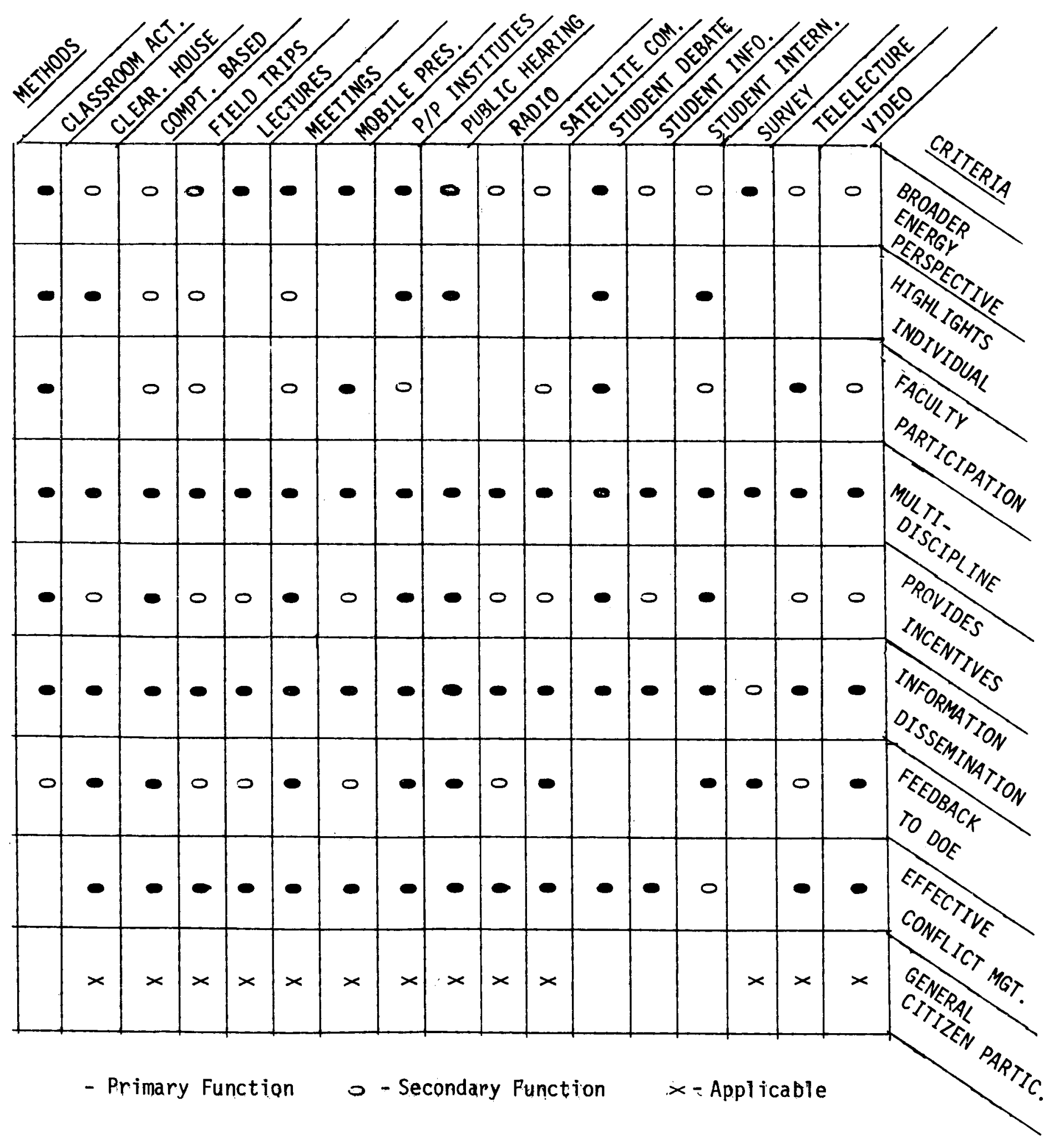




\section{KEY ISSUES AND GENERAL OBSERVATIONS}

The attempt by DOE's Office of Energy Research to significantly involve citizens in the discussion of a high technology such as SPS at this early stage of development is no minor challenge. The previous section has attempted to outline those techniques which will be most useful to encourage the student element of the population to play an active and participating role in the SPS discussion.

It should be evident that no single method will be applicable for all students, and that a combination of techniques will compliment the overall effort for student participation. Those who will have the ultimate responsibility to decide which techniques to adopt should be mindful of the conditions which have led to requests for increased citizen participation in the discussion of science issues, the current state of affairs on campus, and an assessment of how to incorporate student participation as a natural element of the on-going SPS discussion.

Throughout the study, certain questions kept recurring, which are key to the determination of how students can most meaningfully participate in the discussion:

\section{A. EXTENT AND AMOUNT OF INVOLVEMENT}

To what extent and how much involvement does DOE want from students? If adding citizen/student participation to the system does in fact further complicate the process, to what degree is DOE interested in involving students?

If DOE is interested in the ideas and opinions of a small number of highly-qualified students, then this will influence which method to select. Working with a small group may simplify the evolution within this "complicated process" to include citizens, and establish a base on which to build 
participation by more students.

On the other hand, recognizing that we are dealing with a complicated process presents the challenge to simplify and rationalize student opportunities from the start. To what extent is DOE willing to meet this challenge? B. CAPACITY TO MANAGE INVOLVEMENT

What is the capacity of DOE to manage student involvement and participation? In a discussion with Department of State officials concerning student participation in the consideration of issues related to the U.N. Conference on Science and Technology for Development, it was suggested to the Forum that we not encourage too much student input and inquiries to their office because they did not "have the staff to respond to a large amount of questions and comments from students." This comment came several months after the Forum had been encouraged to proceed with plans to develop opportunities to increase student awareness of the issues related to UNCSTD.

While the Forum had not entered into any type of formal agreement with the State Department to pursue student participation, it was certainly disappointing to learn that a major program involving science issues did not have a sufficient staff to respond to student interest. To insure that a similar situation does not occur within the SPS discussion, the Forum would appreciate some assessment by DOE of their ability to manage the student response that we believe can be generated around the topic of SPS. C. UTILIZATION OF STUDENT PARTICIPATION

How will student participation and responses to the SPS discussion be utilized? There exists a growing cynicism that agency plans are a?ready determined when citizen participation is requested. The process from this point on is seen as a mere attempt to meet the minimum legal requirement for citizen input. 
The Office of Energy Research will have to indicate how the participation will be incorporated into the on-going planning process, and assure that the results of this participation will be considered along with other information and data.

D. AVAILABLE FUNDING FOR STUDENT PARTICIPATION

How much funding can be made available to develop student participation in the SPS discussion? While the usual answer to this question is "how much will it take," the wide range of options and combinations requires the establishment of financial boundaries and commitments that can be made available to a student participation effort. Because of the unique cash-flow situation faced by most student organizations, an early indication should be given of when financial support for activities can be anticipated.

E. INTERFACE WITH EDUCATION DIVISIONS

What will the involvement be of the education divisions of DOE, and NASA, and the Office of Education in developing student participation opportunities? As a DOE memorandum on energy education stated:

"It is natural and appropriate that DOE technology programs promote their interests as effectively as possible. This will, however, inevitably bring a program office into conflict with an office attempting to present all relevant information, pro and con, on a technology which has stimulated intense public debate (e.g., recall the breeder program's objections to a National Science Teachers Association fact sheet produced under contract to ERDA's Office of Public Affairs)."16

While the authors have no doubt that the SPS Project Office wants to present all pros and cons of the issues, we do believe that a definite understanding should be reached between the Office of Energy Research and appropriate education divisions of DOE, NASA, and OE regarding student participation. This understanding is particularly important to the authors' belief that the SPS student involvement must take place within a larger energy discussion. 
F. PLANNING

Will DOE give adequate attention to the planning needs of a student participation program? Student participation cannot be initiated at the last minute. It requires as much careful preparation as the technical aspects of the "concept development and evaluation plan." Student participation activities are also complex because they involve integration with the traditional classroom environment and encompass a wider range of individuals. As the DOT citizen participation guide observed:

"Technical work done poorly is an expensive loss, but mistakes can usually be undone given time and money. Citizen participation done poorly can prevent the work from ever being done again and undo all the good technical work that went along with it as we11."17

G. IIMING

When will DOE initiate a student SPS participation program? Because student participation will have to be coordinated around the academic year schedule, the timing of certain steps becomes critical. An announcement of the SPS study objectives must be made to the academic community, followed by the dissemination of SPS educational materials. These materials are necessary to create a basic understanding of the SPS program in general, as well as to clarify specific issues. The steps which follow next (outlined in the "Recommendations" section of this paper) are all dependent upon when DOE makes the announcement that it is initiating a student SPS participation program. 


\section{RECOMMENDATIONS FOR FURTHER STUDY}

A. RECOMMENDATIONS FOR STUDENT PARTICIPATION IN SPS DISCUSSION

1. DOE SHOULD AWARD GRANTS FOR THE DEVELOPMENT OF SPS STUDENT PROGRAMS.

We recommend that by no later than December 1, 1978, DOE release a

"Request For Proposals" to initiate programs to involve students in the discussion of SPS issues. The number of grants to be awarded will depend on many of the factors brought up in Section IV of this paper, but it would be advisable to sponsor between 5 and 10 programs. The amount of funding for each grant also depends on questions raised in Section IV.

Responses to the RFP should be received by DOE no later than April 1 , 1979. At this time a selection committee comprised of representatives from the SPS Project Office, appropriate education offices, and from the student and faculty communities, would evaluate the proposals and select those to receive support. The programs would be conducted during the 1979-80 academic year to conclude in March 1979. Evaluations of the projects would take place between April and June, with a report to be forwarded to the SPS Project Office for inclusion in the final Project Report, due at the end of 1980 . If the capabilities to manage the funded programs does not exist within the current structure of $D O E$, then it is our recommendation that the task of Project Management/Coordination be contracted to an appropriate organization or institution. This Project Management task would include the development of a mail list to send the RFP. Such a list should include colleges, national, state, and local organizations, student societies, and others who are actively working in the field of student education activities. Just a few of the likely candidates who would be interested in sponsoring a student SPS project include: 
- over 120 campus-based academic programs organized around the theme of science and society (identified in the EVIST DIRECTORY -Ethics and Values in Science and Technology);

- 280 professional organizations and societies affiliated with the American Association for the Advancement of Science;

- the Free University Network, a nationwide network that offers non-traditional courses to over 300,000 students;

- over 100 colleges who sponsor Model United Nations Programs;

- the networks of the Institute of International Education and the National Association for Foreign Student Affairs;

- the 40 organizations associated with the Council on Students and Youth, an informal network of national organizations with headquarters in Washington, D.C.; and,

- the national, state, and local networks of organizations interested in projects related to appropriate technology issues.

The above mentioned networks are not meant to be a complete list, but demonstrates thataccess to representative student groups can be built upon existing structures.

To establish a close working relationship between the selected project hosts and the on-going SPS study team, it is recommended that the Program Manager, or other members of the SPS study team, make site visits. These visits should take place early in the process to provide guidance and suggest ideas for project activities and events before they actualiy get underway. This type of cooperation between project organizers and the SPS study team would also help guarantee that a balanced approach was being maintained and that new information and study results would be made available.

Finally, the Program Manager's role would also carry the responsibility to serve as a liaison among the different projects, to share information, ideas, and experiences that are proving most effective in working with students. This information would be disseminated through correspondence and during the site visitations. 


\section{DEVELOP AN SPS SOURCE PUBLICATION}

Because of the lack of SPS educational materials which have been generated for the layperson, we recommend that a SPS SOURCE PUBLICATION be produced. Information in the publication should include:

- basic information on the SPS project and the surrounding issues;

- an assessment of the advantages and disadvantages of the technology;

- an indication of hOW DOE will arrive at a decision regarding the future of SPS;

- a bibliography and reference list of organizations interested in the SPS topic; and,

- information on individuals who have expertise on certain aspects of the SPS discussion, and those who are available to speak on their area.

In addition to being mailed to the public upon request, this publication could serve as the basic background document on which to build each of the previously recommended SPS student programs. Because of its importance as a background publication, we recommend that this document be produced no later than January 1, 1979.

3. DEVELOP A CLASSROOM ACTIVITIES MANUAL

We recommend that a CLASSROOM ACTIVITIES MANUAL be produced which suggests possible ways to incorporate the SPS discussion into specific disciplines. Such a manual could be helpful to students during the second half of the 1978-79 academic year and therefore should be available no later than mid-January 1979.

4. DEVELOP A LIST OF FOTENTIAL FIELD TRIP SITES We recommend that alist be produced for DOE which outlines potential places to go for students interested in making field trips. Such a list would include rectenna sites; aerospace manufacturing plants; utility offices; 
headquarters of environmental organizations; government agencies; etc.. It is recommended that this list be prepared by March 1, 1979.

5. DEVELOP A LIST OF MEETINGS RELATED TO SPS

We recommend that a list be prepared which projects upcoming conferences where the topic of SPS will be discussed. Such a list could be updated on a monthly basis, with the first edition appearing in February of 1979.

6. IDENTIFY PUBLIC HEARINGS APPROPRIATE TO SPS

We recommend that a list be prepared which identifies possible public hearings that will take place at the local, state, and Federal level where the SPS topic may be discussed. This list could also be updated on a periodic basis, with the first edition appearing in March of 1979.

7. IINVENTORY EDUCATIONAL MATERIALS RELATED TO SPS

We recommend that DOE begin to inventory educational materials -slides, film strips, video tapes, brochures, etc. -- which discuss SPS and would serve as appropriate resource materials for students.

8. RECOMMEND SPS TOPIC FOR NATIONAL DEBATE

We recommend that DOE take the initiative to suggest to the American Forensic Association, that the national debate topic (at the college level) in $1979-80$ be associated with SPS or a broader energy question. The AFA generally makes their selection in May of each year so such an initiative should be undertaken no later than April of 1979.

9. ASSIGN INTERNS TO FUTURE SPS CONTRACTS

We recommend that all future contracts awarded for components of the SPS study include funding for student intern positions. This recommendation goes beyond the socioeconomic study to include the other functional study areas. 
10. SURVEY COLLEGE STUDENT ATTITUDES ON SCIENCE AND TECHNOLOGY ISSUES We recommend that DOE cormission a national survey to assess student attitudes on science and technology issues, to include topics related to the SPS study. Such a survey could either be conducted by a professional polling organization, or perhaps as a student initiated project at the local level. We suggest that the survey be taken during the 1979-80 academic year.

\section{DEVELOP A SPEAKERS BUREAU FOR SPS ISSUES}

As the topic of SPS gains in popularity as an area of interest among students, there will be a greater demand for qualified speakers to address campuses and organizations. We recommend that all future recipients of SPS study contracts be required to make a commitment to conduct at least three oral presentations before public and student audiences.

12. CONTRACT STUDENTS TO BUILD SPS MODELS

Because of the shortage of three-dimensional models on SPS, we recommend that DOE contract with industrial arts classes to build scaie models to represent SPS. Iniatiation of such a contract will depend on the final system definition for SPS.

\section{CREATE A CLEARINGHOUSE ON SPS}

Since DOE is concerned with the need to maintain an open system of communication and information exchange for the SPS project, we recormend that consideration be given to creating a SPS Clearinghouse. Such a clearinghouse would be charged with the responsibility of responding to student requests for information, cataloging all new SPS materials, and working with organizations and agencies interested in the subject. It is conceivable that many of the above recommendations (numbers 2 - 12) could be managed by the clearinghouse. 


\section{APPOINT STUDENTS TO SPS ADVISORY COMMITTEES}

To give students a meaningful role in the actual decision-making process related to the SPS Project, we recommend that college students be appointed to appropriate SPS advisory committees -- either existing bodies or those planned for the future. The selection process should remain consistent with current Federal policies pertaining to similar advisory committees within the goverment.

B. RECOMMENDATIONS FOR STUDENT PARTICIPATION TO OTHER ISSUES

Because in-depth documentation of student participation activities needs to be advanced, the authors would like to make some recommendations for further study which might grow from the SPS program.

1. EVALUATE THE STUDENT SPS PROGRAMS AS PILOT PROJECTS FOR OTHER STUDENT-GOVERNMENT COOPERATIVE VENTURES

We recommend that, no matter what structure is eventualiy selected to involve students in the SPS discussion, an evaluation be made of the program. This evaluation could prove helpful for future projects where government agencies request student participation.

2. SURVEY OTHER GOVERNMENT AGENCIES FOR POTENTIAL STUDENT PARTICIPATION PROGRAMS

We recommend that the Federal Interagency Committee on Education conduct a survey of their member agencies in order to identify other issues and opportunities for college student involvement.

3. CIRCULATE THIS WHITE PAPER TO A LARGE AUDIENCE

In order to improve upon the findings of this paper and to increase the number of available documents related to student participation, we recommend that DOE give this paper a wide circulation. It is the authors' belief that this document can serve as a base to build and improve the available literature on student participation programs. 


\section{CONCLUDING REMARKS}

It is the belief of the Forum that student participation should be taking place at all levels of government and with a wide range of issues. The assessment of methods presented in this paper is just the beginning of an evaluation of how student participation in the discussion of these issues can be implemented.

The following exerpt from an article by Albert Rosenfeld, currently Science Editor of SATURDAY REVIEW magazine, summarizes why this broadbase involvement and understanding of issues is important:

"It is fitting that doctors and scientists, who are most closely associated with new developments, are the first to express their concerns. But everyone will have to be concerned. It would be hard to exaggerate either the challenges or the opportunities for educators, for business leaders, for legislators, artists, writers, theologians, philosophers -- and for you and me, personally.

One of the weightiest burdens is bound to fall on the statesmen and leaders of men, both nationally and internationally. They are, of course, already confronted with enormous problems brought on by science and technology. Nuclear weaponry...chemical and biological warfare...As space gets increasingly cluttered with hardware, a body of space law becomes imperative... Worldwi de weather control,...exploitation of the oceans' resources... The need to face this complexity of problems takes on more acute urgency.

The most tempting solution is to let things ride and pay as little attention as possible to these mind-boggling developments. But a decision to ignore them is simply a decision to turn them over to any unscrupulous opportunist who chooses to employ them for his own ends."18

It is our belief that we must start at the earliest possible date to develop educational programs to assist students to understand the ir role in managing these "mind-boggling" developments.

Finally, the effective integration of student participation into the planning discussion of a high-scale technology is a gradual process, and involves a long-range effort and commitment. The results of this process 
require new methods of evaluation and an on-going discussion to make improvements and adjustments to increase the effectiveness and number of opportunities.

We would like to conclude at this point and share the advice from R. Buckminster Fuller's book, EDUCATION AUTOMATION:

"The first effort of planning by students and its design implementation may be expected to disclose great amateurishness and inadequacies, but out of these inadequacies and amateurishness should emerge criticisms from the politicos, economists, and industrialists, excited by students ' plans treading on their doorsteps, out of which criticism on the next round would be improved." 19 


\section{REFERENCES}

1. National Aeronautics and Space Administration and U.S. Department of Energy, Satellite Power System Concept Development and Evaluation Program Plan, February 1978, U.S. Government Printing Office, Stock No. 061-000-0031-3.

2. PRC Energy Analysis Company, Statement of Work, July 18, 1978.

3. Department of Energy Memorandum from Robert Mason to James Kellett, "Education in the Department of Energy," January 17, 1978, p. 3.

4. Robert Theobald, Beyond Despair: Directions for America's Third Century, The New Republic Book Company, Washington, D.C. (1976).

5. League of Women Voters, "Final Report on Energy Conservation Technology Education Program," Department of Energy, Contract No. EC-77-C-01-2165, July, 1978.

6. Steven Ebbin and Raphael Kasper, Citizen Groups and the Nuclear Power Controversy, MIT Press, (1974) p. 244.

7. Edward Cornish, The Study of the Future, World Future Society (1977), p. 215.

8. Scientific Manpower Commission, Manpower Comments, Vol, 15, No. 4, May 1978, p. 22.

9. Cornish, op. cit., p. 226.

10. John Dewey, Experience and Education, Collier Books, New York City (1963).

11. For a complete discussion on general education review, see Earl McGrath"s "Interdiscipl inary Studies: An Integration of Knowl edge and Experience," Change Magazine of Learning, Special issue on "Report on Teaching." Summer, 1978.

12. U.S. Department of Transportation (DOT), Effective Citizen Participation in Transportation Planning, Vol 1, (1976).

13. The authors interviewed Fred Koomanoff on June 12, 1978.

14. Capital Systems Group, Inc., Improving the Dissemination of Scientific and Technical Information: A Practitioner's Guide to Innovation, Washington, D.C. (1976), III. 7. 1.

15. Barry Zinn, Advanced Systems, Incorporated, in letter to Leonard David, August 10, 1978.

16. Mason, op. cit., p. 17. 
17. DOT, op. cit., VOL II.

18. Albert Rosenfeld, "Will Man Direct His Own Evolution?" Life Magazine, October 1, 1965.

19. R. Buckminster Fuller, Education Automation: Freeing the Scholar to Return to His Studies, Southern Illinoìs University Press, (1972) 
Satellite Power Systerns (General)

1. Abdulezer, Loren and Allan Sirota. Space Solar Power: Considerations in Feasibility, Environment, Economics and Other Policy Issues. Polytechnic Insti tute of New York, 1978 (Draft)

2. Bearse, Stacy. "Do We Really Want SPS?," Microwaves, June, 1978, p. 36.

3. Bloomquist, Charles E. A Survey of Satellite Power Stations. PRC Systems Sciences Company (PRC R-1844), September, 1976.

4. Citzens' Energy Project. "Sizing Up Solar Satellites." People \& Energy, May, 1978, pp. 3-4.

5. Citzens' Energy Project. Solar Space Satellites, Report Series \#40, June, 1978.

6. Cousins, Norman. "Growing Your Own Fuel," Saturday Review, September 30, 1978, p. 28.

7. David, Leonard. "SPS-Time to Pull the Plug?," FASST News, Vol. 7, No. 1 \& 2, Winter/Spring, 1978, pp. 6-7, 16-17.

8. Department of Energy. Policy Statement on SPS, by the Administrator, DOE, November, 1977.

9. ECON, Inc. Political and Legal Implications of Developing and Operating a Satellite Power System. Report prepared for Jet Propulsion Laboratory, August 15, 1977.

10. Energy Research and Development Administration. Final Report of the ERDA Task Group on Satel1ite Power Stations (ERDA-76/148), November, 1976.

11. Glaser, Peter. "Development of the SPS" - Testimony before hearings of the subcormiteee on Aerospace Technology and National Needs, Committee on Aeronautics and Space Sciences, U.S. Senate, January 19, 1976.

12. Glaser, P.E. "Solar Power Satellite Developments," The Journal of the Astronautical Sciences, Vol. XXVI, No. 2, April-June, 1978, pp. 101-127.

13. Glaser, P.E. "SPS Development - the Next Steps." Testimony before Subcommittee on Space Sciences and Applications and the Subcommittee on Advanced Energy Technologies \& Energy Conservation R\&D\&D, Committee on Science and Technology, U.S. House of Representatives, Apri1 14, 1978.

14. Glaser, P.E. "SSPS - A Step Towards the Industrial Use of Space," Presented before International Astronautical Federation, XXVI Congress, Lisbon, Portuga 1, September, 1975.

15. Glaser, P.E. "SPS: The Promise and the Challenges," AAAS Annual Meeting, Washington, D.C., February, 1978. 
16. Hochschild, Adam. "Shuttling Manhattans to the Sky," Mother Jones, May, 1978, pp. 37-51.

17. Marshall Space Flight Center/Johnson Space Center, Solar Power Satellite Baseline Review, Preliminary Study, July 13, 1978.

18. National Aeronautics and Space Administration/Department of Energy, Satellite Power System (SPS) Concept Development and Evaluation Program Plan, July 1977 - August 1980. February, 1978.

19. Rhea, John. "Support Builds for SPS," Industrial Research \& Development, July, 1978, pp. 35-36.

20. Sunsat Energy Council. Space Solar Power Newsietter, Vol. 1, No. 1, May 3, 1978.

21. Universities Space Research Association. Report on the Solar-Power Satellite Task Group, Houston, Texas, March 1978.

Solar Systems/Terrestrial

22. Department of Energy. Guide to Solar Energy Programs, Revised Edition, (DOE/ET-0036/1), June 1978.

23. Department of Energy. National Photovoltaic Program Plan/February 3, 1978, (DUE/ET-0035(78)), March, 1978.

24. Department of Energy. Photovoltaic Program, Program Summary, (DOE/ET$0019 / 1$ ), January, 1978.

25. Department of Energy. Solar Energy - A Status Report, (D0E/ET-0062), June, 1978.

26. Department of Energy. Solar Thermal Power Systems Program, Program Summary, January, 1978.

27. Executive Office of the President. The National Energy Plan, 1977.

28. General Accounting Office. How Solar Energy was Treated in the AEC Chairman's Report, 'The Nation's Energy Future.', (B-178205), October 18, T974.

29. Hoffman, Allan R. Status Report on Solar Energy Domestic Policy Review, (Public Review Copy), August 25, 1978.

30. MITRE Corporation. Solar Energy Systems (M73-26), March, 1973.

31. MITRE Corporation. Systems Analysis of Solar Energy Programs (MTR--6513), December, 1973.

32. Murray, Bruce, "Solar Energy: True God or False Prophet?, Engineering \& Science, Calif. Inst. of Tech., March-April, 1978, pp. 4-17, 35-36. 
33. National Science Foundation. Solar Energy as a National Energy Resource (NSF/RA/N-73-001), December, 1972.

34. Uffice of Technology Assessment. Applications of Solar Technology to Today's Energy Needs, U.S. Congress, Washington, D.C., June 1977. (Prepublication draft)

35. Office of Technology Assessment. Application of Solar Technology to Today's Energy Needs - Volume 1, U.S. Congress, Washington, D.C., June 1978.

Science, Technology and Citizen Participation

36. American Association for the Advancement of Science (AAAS). Science Court Bibliography, Office of Special Programs, March 1977.

37. Berg, Mark R., and D.N. Michael. Summary Report: Factors Affecting Utilization of Technology Assessment Studies in Policy-Making. Center for Research on Utilization of Scientific Knowledge, Institute for Social Research, The University of Michigan, 1978.

38. Black, Guy. Technology Assessment - What Should It Be?, Staff Discussion Paper 211, Program of Policy Studies in Science and Technology. The George Washington University, Washington, D.C., June, 1971.

39. Cirone, William J. "Using an Institution as an Umbrella for Conmunity Development and Citizen Participation Projects," Center for Community Education and Citizen Participation, Santa Barbara, Calif., 1978.

40. Coates, Joseph F. "Some Methods and Techniques for Comprehensive Impact Assessment," Technological Forecasting and Social Change, June, 1974, pp. 341-357.

41. Coates, J.F. "Technology Assessment - A Too1 Kit," CHEMTECH, June, 1976, pp. 372-383.

42. Coates, J.F. "Technology Assessment," Reprint from McGraw-Hill Yearbook on Science and Technology, McGraw-Hiil Book Company, Inc., New York, 1974.

43. Coates, Vary T. Emerging Trends in Technology Assessment, Monograph No. 19, The George Washington University, Wash., D.C., April 1974.

44. Coates, V. T. Technology and Public Policy, Volumes $1 \& 2$, and Summary Report. Program of Policy Studies in Science and Technology, The George Washington University, Wash. D.C., July 1972.

45. Committee for the Future, Inc. Horizons Day-Citizens Initiatives, Washington, D.C., July 1976.

46. Cutcliffe, S.H. Humanities Perspectives on Technology Newsletter, No. 6, Curriculum News letter of the Lehigh University HPT Program, Lehigh University, Bethlehem, Pa., June, 1978. 
47. Decker, Craig. Editor of Technology and Politics - A New Newsletter and Forum, Washington, D.C. (no date)

48. Department of Energy. Public Meeting on Solar Technology, August 8-9, 1978, Washington, D.C., August $15,1978$.

49. Department of Energy. Solar Energy Policy Forum's/Region I through $X$. Consumer Outreach Program, DOE, 1978.

50. Department of Transportation. Effective Citizen Participation in Transportation Planning, Volume I and II, Federal Highway Administration, Wash., D.C., 1976.

51. Ebbin, Steven and Raphael Kasper. Citizen Groups and the Nuclear Power Controversy - Uses of Scientific and Technological Information, The MIT Press, Cambridge, Mass., 1974.

52. Environmental Action Foundation. A Citizen's Guide to the Fuel Adjustment Clause, Wash., D.C., August 1975.

53. Hanchey, James R. Public Involvement in the Corps of Engineers Planning Process, IWR Research Report 75-R4, Fort Belvoir, Virginia, 0ct. 1975.

54. Hawk, Ernest. Technology and Society - Audio/Visual Resources Digest. The Pennsylvania State University, Increasing Public Understanding of Technology (INPUT) Program, 1977.

55. Heitowit, Ezra D. and Janet Epstein. Listing of Courses and Programs in the Field of Ethical and Human Value Implications of Science and Technology. Cornell University, Program on Science, Technology, and Society, Jan. 1, 1978.

56. Kates, Robert W. Editor, Managing Technological Hazard: Research Needs and Opportunities, Inst. of Behavioral Science, Univ. of Colorado, 1977.

57. La Follette, Marcel C. The Citizen and Science Almanac \& Annotated Bibliography, The Poynter Center, Indiana University, Bloomington, Indiana, 1977.

58. Lawless, Edward W. Technology and Social Shock, Rutgers University Press, New Brunswick, New Jersey, 1977.

59. "Limits of Scientific Inquiry" Daedalus, a Journal of the American Academy of Arts and Sciences, VoT. 107, No. 2. Harvard University, Cambridge, Mass., Spring 1978.

60. Lindsay, James F. "The Impact of Technology on Society," Engineering Education, Wash., D.C., Vol. 67, No. 8, May 1977, pp. 753-756.

61. Mazur, Allan. "Science Courts," MINERVA - A Review of Science, Learning and Policy, Vol. XV, \#1, Spring, 1977, pp. 1-14. 
62. Milbrath, Lester $W$. Incorporating the Views of the Uninterested but Impacted Public in Environmental Planning, Environmental Studies Center, State Univ. of New York at Buffato, April 26, 1978.

63. MITRE Corporation. Public Participation in Energy Related Decision Making, McLean, Virginta, Jan. 1977.

64. Murray, Francis $X$. Where We Agree, Report of the National Coal Policy Project, Vol. 1 and 2, Westview Press/Boulder, Colorado, 1978.

65. Nelkin, Dorothy, and Michael Pollak. "The Politics of Participation and the Nuclear Debate in Sweden, the Netherlands, and Austria," Public Policy, Vol. 25, \#3, Summer 1977, pp. 333-357.

66. 0'Toole, James and the Univ. of Southern Calif. Center for Futures Research. Energy and Social Change, The MIT Press, Cambridge, Mass., 1976.

67. Priscoli, Jerry D. Public Involvement and Social Impact Analysis: Union Looking for Marriage, Working Paper 78-2, Inst. for Water Resources, Fort Belvoir, Virginia, Jan., 1978.

68. Roelofs, Robert with Joseph Crowley and Donald Hardesty. Environment and Society, Univ. of Nevada, Reno.. Prentice-Hall, Inc., Englewood Cliffs, New Jersey, 1974.

69. Rosenbaum, Nelson M. Citizen Involvement in Land Use Governance - Issues and Methods, The Urban Institute, Wash., D.C., 1976.

70. Scribner, Richard A. and Frances Zorn. Science and Social Issues: Stimulating Discussion and Involvement, AAAS Report No. 76-R-7, Wash. D.C., Juty, 1976.

71. "Science and Its Public: The Changing Relationship." Daedalus, a Journal of the American Academy of Arts and Sciences, Vo1. 103, No. 3, Harvard Univ., Cambridge, Mass., Summer 1974.

72. Science for Cittzens - A Program Plan of the National Science Foundation. Prepared for the Committee on Labor and Public Welfare, U.S. Senate and the Committee on Science and Technology, U.S. House of Representatives, Volume I, Part I and 2, Feb., 1976.

73. Shelanski, Vivien B. Editor, Newsletter on Science, Technology, and Human Values. Number 24, Harvard Univ., Cambridge, Mass., June 1978.

74. Sigma Research, Inc. Workshop Proceedings: Environmental and Social Impacts of an Electricity Shortage, Prepared for Electric Power Research Institute. (EPRI EA-796-SR/WS-77-24), Special Report, June 1978.

75. Small, Henry. Editor, 4S/Society for Social Studies of Science News letter. Vol. 3, No. $i$, Corneli Univ., Ithaca, New York, Winter 1978.

76. U.S. National Academy of Sciences. Science, Technology and Society - A Prospective Look, Summary and Conclusions of the Bellagio Conference, 1976. 
General Energy/Education Material

77. American Association for the Advancement of Science (AAAS). Ethics and Values in Science and Technology: Resource Directory. Office of Education, AAAS, 1978.

78. American Association for the Advancement of Science (AAAS). NSF ChautauquaType Short Courses for College Teachers, Academic Year 1974-1975, Office of Science Education, AAAS, 1976.

79. American Nuclear Society Eastern Regional Student Conference. Transactions 1977, North Carolina State University, North Carolina, March 24,25 and 16, 1977.

80. Atomic Energy Commission. A Teacher's luide for the Environmental Impact of Electrical Power Generation: Nuclear and Fossil (WASH-1262), Wash. D.C., November, 1973.

81. The Biological Sciences Curriculum Study - A Center at the University of Colorado. BSCS Newsletter, No. 67, April, 1977.

82. Council for Education Development and Research, Education Confronts the Energy Dilemma, Proceedings of the Sixth Annual Conference Council for Educational Development and Research (Conf-7760701), June 22-24, 1977.

83. Department of Energy. Activities of the Department of Energy in Energy Education (DOE/IR-0008 UC-13), Office of Education, Business and Labor Affairs/DOE, Wash., D.C., March 1978.

84. Department of Energy. Memorandum on Education in the Department of Energy, from Robert W. Mason to James Kellett/DOE, Wash., D.C., January 17, 1978.

85. ERIC Information Analysis Center for Science, Mathematics, and Environmental Education of the National Institute of Education. A Compilation of Entries from a Directory of Projects and Programs in Environmental Education, 4th Edition, ERIC, Wash., D.C., December, 1976.

86. Federal Energy Administration. Energy Activity Guide, Park Project on Energy Interpretation, Wash., D.C. (no date)

87. The Ford Foundation. Exploring Energy Choices - A Preliminary Report of the Ford Foundation's Energy Policy Project, Wash., D.C., 1974.

88. Fowler, John M. "Energy, Education and the 'Wolf' Criers," Reprint from The Science Teacher, Vol. 43, No. 3, Wash., D.C., March 1976.

89. Lopez, Lois V. Education Directory. U.S. Department of Health, Education, and Welfare (HEW \# (OE) 76-01040), Wash., D.C., 1976.

90. Murray, Francis X. Energy: A National Issue, The Center for Strategic and International Studies, Georgetown University, Wash., D.C., 1976. 
91. National Science Foundation. Science Resources Studies, Program Report Vol. 2, No. 2, Wash., D.C., May 1978.

92. National Science Teachers Association. Energy-Environment Materials Guide, Wash., D.C., 1975.

93. National Science Teachers Association. Energy Fact Sheets (1-19) Washington, D.C. (undated)

94. National Science Teachers Association. How a Bill Becomes a Law to Conserve Energy, Grades 9, 11, 12. Interdisciplinary Student/Teacher Materials in Energy, the Environment, and the Economy, (EDM-1033), Wash., D.C., August, 1977.

95. RAIN - Journal of Appropriate Technology. Vol. IV, No. 10, August/September 1978.

Communication Mechanisms

96. Barnes, Bart. "Maryland University Launches Own TV Network to Broadcast Courses," Washington Post, September 14, 1978, p. D.C. 2.

97. Capital Systems Group, Inc. Improving the Dissemination of Scientific and Technical Information - A Practitioner's Guide to Innovation, Prepared for the Office of Science Information Service, National Science Foundation, Rockville, Maryland, 1977.

98. Center for Environmental Conflict Resolution. Environmental Mediation: An Effective Alternative?, A Report of a Conference held in Reston, Virginia, Jan. IT-13, 1978.

99. Chacko, George. Toward an Integrated Communication System, Presented at 143rd Annual Meeting of the AAAS, Feb. 23, 1977.

100. College \& University Radio Stations, Listing 1978 (source unknown).

101. Dickson, Edward M. and Raymond Bowers. The Video Telephone, a New Era in Telecommunications: Preliminary Technology Assessment, Cornell University, prepared for National Science Foundation (NSF-RA-S-73-004), June, 1973.

102. Department of Energy. Energy Information Data Bases, DOE Technical Information Center, Wash., D.C., Jan. 1978. (TID-22783)

103. Draves, Bill and Cathy MacRunnels. Editors, The Free U Manual A National Guide to Operations of a Free University, Univ. for Man, Manhattan, Kansas. First Edition, Summer 1978.

104. Educational Resources Information Center. How To Use Eric, Central ERIC, National Institute of Education, Wash., D.C. (undated)

105. Energy Research and Development Administration. Technical Assistance Program/Resources Guide, Tech. Info. Center, Oak Ridge, Tenn., May 1977. 
106. Engineering Colleges Magazine Association. Listing 1978 (source unknown)

107. Environmental Protection Agency. Who's Who in the Interagency Energy/ Environment R \& D Program, EPA Decision Series (EPA-600/9-77-011), Wash., D.C., June 1977.

108. General Accounting Office. Observations on Collection and Dissemination of Scientific, Technical, and Engineering Information, National Technical Information Service, Department of Commerce - A Report of the Comptroller General of the United States (GGD-76-66). Wash., D.C., March 19, 1976.

109. Greenberger, Martin. Computer and Information Networks, Science, October 5, 1973, pp. 29-35.

110. Heller, Paul S. Editor, Edunet News, Numbers 7 \& 8, Spring 1978.

111. Interuniversity Communications Council, Inc. "How to Use Telenet The Packet-Switched Network for Data Communications (Information for Terminal Users), Princeton, New Jersey (no date).

112. Johansen, Robert, Jacques Vallee, and Kathleen Spangler. "Electronic Meetings: Utopian Dreams and Complex Realities," The Futurist, Vol. XII, No. 9, pp. 313-319.

113. Kulakow, Allan M. Beyond Open Access, the Real Communications Revolution, (Preliminary Draft), January 1974.

114. "Media Guide to Nuclear Experts." Atomic Industrial Forum, Inc., August 1977.

115. National Educational Advertising Services, Inc. Characteristics of the College Market (1975). New York, New York, 1975.

116. The National Education Association. The Use of Satellite Communications To Increase Professional Communications Among Teachers, Wash., D.C., July 30, 1974.

117. National Science Foundation. Operational Trials of Electronic Information Exchange for Small Research Communities, Scientific, Technological and International Affairs, Division of Science Information, Wash., D.C., January, 1977.

118. Public Service/Educational Radio Stations. Listing 1978 (source unknown).

119. Rensselaer Polytechnic Institute. Video Tapes: Phase One of the Modern Technological Methods for Improving the Quality of Education, Minutes of Meeting for the National Academy of Engineering, Wash., D.C., May 25, 1978.

120. Salloway, Niti. Video at MIT - A Progress Report, Center for Advanced Engineering Study, MIT, Cambridge, Massachusetts, May 10, 1978.

121. Satellite Business Systems. Project Prelude: Communications of the $80^{\prime} \mathrm{s}$, Evaluation Report on Project Prelude, Experiment No. 26 in the CTS Program, McLean, Virginia, May 30, 1978. 
122. Turoff, Starr and Roxanne Hiltz. "Meeting Through Your Computer," IEEE Spectrum, May 1977, pp. 58-64.

123. Turoff, Murray. The Potential Role of Graphics in Computerized Conferencing Systems, Presented at the 144th Annual Meeting of the AAAS, Feb. 17, 1978.

124. Vallee, Lipinsk, and Miller. "Introduction to Computer Conferencing," Group Communication Through Computers, Vol. 1, Inst. for the Future, 1974.

125. Vallee, Jacques, Robert Johansen and Kathleen Spangler. "The Computer Conference: An Altered State of Communication?", The Futurist, June 1975, pp. 116-121.

126. Wehr, Paul. Conflict Regulation, Study Guide \#7, AAAS Study Guides on Contemporary Problems (no date), American Association for the Advancement of Science, Washington, D.C.

127. Wood, Fred B., Vary Coates, Robert Chartrand, and Richard Ericson. "Video conferencing via Satellite: Opening Government to the People, The Futurist Vol. XII, No. 5, October 1978, pp. 321-326.

Student Programs/Student Involvement

128. Aiken, Henry D. "Youth and Its Rights," The Place of Value in a World of Facts, Proceedings of the Fourteenth Nobel Symposium, Almqvist \& Wiksell Forlag AB, Stockholm, Sweeden, 1970, pp. 359-383.

129. Dewey, John. Experience and Education, The Kappa Delta Pi Lecture Series, Collier Books, New York, New York, 1963.

130. Fuller, Buckminster. Education Automation - Freeing the Scholar to Return to his Studies. Southern IIllinois Univ. Press, Feffer \& Simons, Inc., 1962.

131. The Gresham Teacher Challenge Conference. A Charette Simulation, New England Program in Teacher Education, New Hampshire, May 1972.

132. Institute of International Education. Annual Report - 1977, New York, 1978.

133. McGarth, Earl J. Should Students Share the Power?, Temple University Press, Philadelphia, Pa., T970.

134. Radtke, Mark. Final Report: Energy Resource Alternatives Competition - 1975, Tufts University, Medford Mass., March T976.

135. Rutherford, James F. Students and Science - A Report of a Conference on Ways to Strengthen AAAS Cooperation with Teachers, Schools, and Youth, AAAS, Wash., D.C., August 1972.

136. Scientific Manpower Commission. Manpower Comments, Vol, 15, No. 4, Wash., D.C. 1971.

137. Student Service Center - Student Advisory Council Project. Massachusetts Students in Decision Making, Final Report (no date) 
138. White House. Listening to Young Voices, White House Conference on Youth, White House, Wash., D.C., 1971.

139. White House. White House Conference on Youth, White House, Wash., D.C., 1971.

140. White House. Report of the White House Conference on Youth - April 18-22, 1971, Estes Park, Colorado, White House, Wash., D.C., 1971.

Future Trends

141. Cornish, Edward with members and staff of the World Future Society. The Study of the Future - An Introduction to the Art and Science of Understanding and Shaping Tomorrow's World, World Future Society, Wash., D.C., T977.

142. Scheiber, Jane L. Editor, America and the Future of Man, Univ. Extension, Univ. of Calif., San Diego. CRM Books, 1973.

143. Spekke, Andrew. The Next 25 Years - Crisis and Opportunity, World Future Society, Washington, D.C., 1975.

144. Theobald, Robert. Beyond Despair - Directions for America's Third Century, The New Republic Book Company, Inc., Washington, D.C., 1976.

145. Theobald, Robert and J.M. Scott. TEG's 1994. Warner Books Edition, New York, New York, 1972.

Miscellaneous

146. Department of Health, Education and Welfare. Carcinogenic Properties of Ionizing and Non-Ionizing Radiation, Vol. II - Microwave and Radio-frequency Radiation. NIOSH Technical Report No. 78-134, Cincinnati, Ohio, March 1978.

147. Department of Health, Education and Welfare. Recombinant DNA Research, Volumes I and II, Documents Relating to "NIH Guidelines for Research Involving Recombinant DNA Molecules." Public Health Service, National Institutes of Health, DHEW Publication No. (NIH) 76-1138, Wash., D.C. August 1976.

148. National Academy of Sciences. Biologic Effects of Electric and Magnetic Fields Associated with Proposed Project Seafarer, Report of the Committee on Biosphere Effects of Extremely-Low Frequency Radiation, Division of Medical Sciences, Assembly of Life Sciences, National Research Council. Washington, D.C., 1977. 
INDIVIDUALS CONTACTED DUR ING RESEARCH

Don Agostino

National Science Foundation

Division: Public Understanding of Science

Washington, D.C. 20550

(202) $282-7770$

Jean Albert

National Science Foundation

Division: Science and Society

Washington, D.C. 20550

(202) 282-7770

Jim Aldrich

Massachusetts Audubon Society

Lincoin, Massachusetts 01773

(617) 259-9500

Al Alibrando

Department of Energy

Division: Press Services

Room 8F073, Forestall B1dg., South

Washington, D.C. 20545

(202) 252-5806

Wil ton Anderson

Energy and Education Action Ctr. $/ 0 \mathrm{E}$

Reporters BIdg., Rm. 514

Washington, D.C. 2020 ?

(202) 472-7777

Arrie Bachrach

Environmental Resource Group

6380 Wilshire Blvd., Suite 804

Los Angeles, California 90048

(213) 653-1086

Stacy Bearse

MicroWaves Magazine

Hayden Publishing Company, Inc.

50 Essex Street

Rochel le Park, New Jersey 07662

(201) 843-0550

Doug Bond

Laboratory for Research in

Scientific Communication

202 Haecker Hall

University of Minnesota

St. Paul, Minnesota 55108

(612) $373-0817$
Karla Borden

Smithsonian Institution

Division: Office of Seminars and Symposia

Washington, D.C. 20560

(202) 381-5587

Ken Bossong, for the

Citizens" Energy Praject

1473 K Street. N.W. . 8th Floor

Washington, D.C. 20005

(202) 393-6700

Francis Bradley

American Society of Engineering

Education (ASEE)

One Dupont Circle, Suite 400

Washington, D.C, 20036

(202) 293-7080

Tom Burroughs

American Chemical Society

1155 16th Street, N.W.

Washington, D.C. 20036

(202) 872-4445

Joe Carvajal

Department of Energy

Division: Consumer Outreach

Program

Washington, D.C. 20585

(202) 252-5141

Charles Chaffer

Foundation for Public Affairs

122016 th Street, N.W.

Washington, D.C. 20036

(202) 354-6233

Steve Del Sesto

Cornell University/STS Program

Clock Hall 607

Ithaca, New York 14850

(607) 256-3810

Bill Draves

Free University

1221 Thurston

Manhattan, Kansas 20500

(913) 532-5866 
Gregg Edwards

National Science Foundation

Division: Materials Development

Washington, D.C. 20550

(202) 283-7904

Will iam Edwards

Advanced Systems, Inc. (ASI)

1901 N. Fort Myer Drive

Arlington, Virginia 22209

(703) 524-2277

Viki Hutchinson

Center for Human Environments

Graduate Center/City Univ. of N.Y. 33 W. 42nd Street

New York, New York 10036

(212) 790-4551

Jeff Irons

American Institute of Aeronautics and Astronautics

1290 Avenue of the Americas

New York, New York 10019

(212) $581-4300$

George James

National Science Foundation

Division: Communications Programs

Washington, D.C. 20550

(202) 634-4333

Raphael Kasper

National Academy of Sciences

2101 Constitution Avenue, N.W.

Washington, D.C. 20418

(202) 389-6864

George Keegan

209 Catherine

Philadelphia, Pennsylvania 19147

(215) 627-5728

Burt $K l$ ine

Health Resources Administration

Center Building, Room 1022

3700 East-West Highway

Hyattsville, Maryland 20783

(301) 436-7263
Sheldon Krimsky

Tufts University/Program on Urban,

Social and Enviromental Policy

Brown House

Medford, Massachusetts 02155

(607) 628-5000 Ext. 6159

Carol Kroll

Student National Educational Assoc.

1201 16th Street, N.W., Suite 1100

Washington, D.C. 20036

(202) . 833-5525

Phil Krystosek

6063 N. Fairview

Agoura, California 91301

(213) 889-6259

Richard Laska

Environmental Protection Agency

Ma il Code: RD-674

Washington, D.C. 20460

(202) 426-9454

MacNeil/ Lehrer Report

WNET/13

P.0. Box 345

356 West 58 th Street

New York, New York 10019

(212) 560-2000

Bettsy Little

Interuniversity Comm. Council, Inc.

P. 0. Box 364

Princeton, New Jersey 08540

(800) 257-9505

Arthur Livermore

Amer. Assoc. for the Adv. of Science

1776 Massachusetts Avenue, N.W.

Washington, D.C. 20036

(202) 467-4400

John Logsdon

George Washington University/

Science Pol icy, Room 714

Washington, D.C. 20006

(202) 676-7292 
Elaine Madden

National Association for

Foreign Student Affairs

186019 th Street, N.W.

Washington, D.C. 20009

(202) 462-4811

$\mathrm{Jim}$ March

Socio-Economic Studies Division

Office of Program and

Policy Planning

Federal Highway Administration, DOT

Washington, D.C. 20590

(202) 426-0262

Mary McGuire

Energy Education Newsletter

National Science Teachers Assoc.

1742 Connecticut Avenue, N.W.

Wa shington, D.C. 20009

(202) 265-4150

Alan Mazur

Syracuse University

Department of Sociology

Syracuse, New York 13210

(315) $423-1870$

Lester Milbrath

State University of New York/ Buffalo

123 Wil keson Quad/Environmenta i Study Group

Buffalo, New York 14261

(716) 636-2595

William Lee Miller

Indiana University/Poynter Center

Bloomington, Indiana 47401

(812) 337-0261

Francis Murray

Center for Strategic \& International

Studies/Georgetown University

Washington, D.C. 20006

(202) 833-1930

Barbara Myers

American Chemical Society

1155 16th Street, N.W.

Washington, D.C. 20036

(202) 872-4478
National Center for

Appropriate Technology

1522 K Street, N.W., Suite 1036

Washington, D.C. 20005

(202) 347-9193

Dorothy Ne1kin

Cornell University/STS Program

Clock Hall 607

Ithaca, New York 14850

(607) 256-3810

Fred Newmann

University of Wisconsin, Dept. of Curriculum Development

225 N. Mills Street

Madison, Wisconsin 53706

(608) 263-6262

Layton 01 son

National Student Education Fund

2000 P Street, N.W.

Washington, D.C. 20036

(202) 785-1856

Bill Pendelton

Ford Foundation

320 E. 43rd Street

New York, New York 10017

(212) $573-5000$

Johñ Piescik

Robert F. Kennedy Memorial

1035 30th Street, N.W.

Washington, D.C. 20007

(202) 338-7444

James Pointdexter

NASA/Johnson Space Ctr./Educ. Prog.

Houston, Texas 77058

(713) 483-2938

Kerstin Pollack

National Academy of Sciences

Assembly of Engineering

Nashington, D.C. 20478

(202) 393-8100

Robert Resnick

Rensselaer Polytech. Institute

Physics Department

Troy, New York 12181

(518) 270-2322 
Carol Rogers

Amer. Assoc. for the Adv. of Sci. 1776 Massachusetts Ave. N.W. Washington, D.C. 20036 (202) $467-4400$

Gail Ruben

National PIRG Clearinghouse

1329 E Street, N.W., Suite 1127 Washington, D.C. 20004

(202) $347-3811$

Ann Ryan

Law Student Division

American Bar Association

1155 Ease 60th Street

Chicago, Illinois 60637

(312) 947-3917

Deborah Sanderson

Energy Impacts Project - M.I.T. Room 40209

Cambridge, Massachusetts 02139

(617) 253-1356

Frank Sandifer

Public Services Laboratory

George Washington University

37 th \& 0 Streets, N.W.

Washington, D.C. 20057

(202) 625-4154

Richard Scribner

Amer. Assoc. for the Adv. of Sci. 1776 Massachusetts Ave. N.W. Washington, D.C. 20036

(202) $467-4475$

Tom Schwab

306 Highland

Cornell Universtiy

Ithaca, New York 14850

(607) 257-1052

Eric Seaborg

Student Press Service

1035 30th Street, N.W.

Washington, D.C. 20007

(202) 338-7444
Borris Sheleg

Naval Research Laboratory

Mail Code: 5258

Washington, D.C. 20375

(202) $767-3526$

Scientists Insti. for Public Infor. 355 Lexington Avenue

New York, New York 10017

(212) $661-9110$

Arnold Strassenburg

American Assoc. for Physics Teachers

Graduate Physics Building

State University at Stony Brook

Stony Brook, New York 11794

(516) $246-6840$

James Sullivan

Department of Art

Southern Illinois University

Carbondale, Illinois 62901

(617) $453-2571$

Ken Thompson

Lincoln Fielen Center for Citizen and Public Affairs

Tufts University

Medford, Massachusetts 02155

(617) 628-5000 Ext. 352

Tom Turner

Box 5982

McDonne11 Douglas Company

St. Louis, Missouri 63134

(314) 838-6436

Frederick Tuttle

Educational Programs/NASA Headquarters

Mail Code: FE

Washington, D.C. 20546

(202) $755-3518$

Barbara Vaughn

RESOLVE

360 Bryant Street

Palo Alto, California 94301 
Harold Ward

Office of the Dean

Brown University

Providence, Rhode Island 02912

(401) 863-1000

Paul Wehr

Institute of Behavioral Science

Uniyersity of Colorado

Boulder, Colorado 80302

(303) 492-8093

Robert Weiss

Independent Film/Television Producer

535 California

Santa Monica, California 90403

(213) 393-7095

John J. Whiteside

Committee for the Future, Inc.

2385 North Porter Street, N.N.

Washington, D.C. 20008

(202) $966-8776$ 